\title{
TNF $\alpha$ induces survival through the FLIP-L-dependent activation of the MAPK/ERK pathway
}

\author{
F Marques-Fernandez ${ }^{1,2,3}$, L Planells-Ferrer ${ }^{1,2,3}, \mathrm{R}$ Gozzelino ${ }^{2,5}, \mathrm{KMO}$ Galenkamp ${ }^{1,2,3}, \mathrm{~S}$ Reix ${ }^{1,2,3}, \mathrm{~N}$ Llecha-Cano ${ }^{4}$, \\ J Lopez-Soriano ${ }^{1,2,3}$, VJ Yuste ${ }^{2}$, RS Moubarak ${ }^{*, 1,2,3}$ and JX Comella*,,2,3
}

Activation of tumor necrosis factor receptor-1 can trigger survival or apoptosis pathways. In many cellular models, including the neuronal cell model PC12, it has been demonstrated that inhibition of protein synthesis is sufficient to render cells sensitive to apoptosis induced by TNF $\alpha$. The survival effect is linked to the translocation of the transcription factor nuclear factor-kappa B (NF- $\kappa \mathrm{B}$ ) to the nucleus and activation of survival-related genes such as FLICE-like inhibitory protein long form (FLIP-L) or IAPs. Nonetheless, we previously reported an NF- $\kappa \mathrm{B}$-independent contribution of Bcl-xL to cell survival after TNF $\alpha$ treatment. Here, we demonstrate that NF- $\kappa \mathrm{B}$-induced increase in FLIP-L expression levels is essential for mitogen-activated protein kinases/ extracellular signal-regulated kinases (MAPK/ERK) activation. We demonstrate that FLIP-L behaves as a Raf-1 activator through both protein-protein interaction and Raf-1 kinase activation, without the requirement of the classical Ras activation. Importantly, prevention of FLIP-L increase by NF- $\kappa$ B inhibition or knockdown of endogenous FLIP-L blocks MAPK/ERK activation after TNF $\alpha$ treatment. From a functional point of view, we show that inhibition of the MAPK/ERK pathway and the NF- $\kappa \mathrm{B}$ pathway are equally relevant to render PC12 cells sensitive to cell death induced by TNF $\alpha$. Apoptosis induced by TNF $\alpha$ under these conditions is dependent on jun nuclear kinase1/2 JNK1/2-dependent Bim upregulation. Therefore, we report a previously undescribed and essential role for MAPK/ERK activation by FLIP-L in the decision between cell survival and apoptosis upon TNF $\alpha$ stimulation. Cell Death and Disease (2013) 4, 493; doi:10.1038/cddis.2013.25; published online 14 February 2013

Subject Category: Cancer

Death receptors (DR) are members of the tumor necrosis factor (TNF) superfamily that comprise in their cytosolic tail a death domain able to initiate a signal transduction cascade ultimately leading to apoptosis. ${ }^{1}$ DRs and their ligands are expressed under physiological conditions in a variety of tissues including the nervous system, especially during development. ${ }^{2-6}$ However, most neurons express DRs without being sensitive to DR-mediated apoptosis. Indeed, activation of DRs also conveys alternative, non-apoptotic signaling pathways involved in cell survival, differentiation, ${ }^{7}$ or the control of inflammatory and immune responses. ${ }^{8}$

The binding of TNF-alpha (TNF $\alpha$ ) to its receptor tumor necrosis factor receptor-1 (TNFR1) can alternatively induce cell death or survival and differentiation through the formation of two sequential complexes. ${ }^{9}$ While complex I triggers rapid activation of the transcription factors nuclear factor-kappa $B$ (NF- $\kappa$ B) and activator protein-1, Complex II is formed after the former is released from the membrane into the cytosol by receptor internalization and endosomal trafficking. ${ }^{10,11}$
Complex II leads to the death-inducing signaling complex formation and ultimately, caspase-dependent apoptosis. $\mathrm{NF}-\kappa \mathrm{B}$ activation following DR stimulation leads to the transcriptional activation of pro-survival genes, such as those encoding for inhibitor of apoptosis proteins cIAP1/2, Bcl-2, Bcl$\mathrm{xL}$ or cellular FLICE-like inhibitory protein. ${ }^{12} \mathrm{NF}-\kappa \mathrm{B}$ activation has been considered as the main pathway leading to differentiation and survival effects induced by TNF $\alpha .{ }^{13,14}$ When NF- $\kappa$ B is activated after complex I formation, FLIP-L translocates to complex II in order to prevent caspase-8 activation. However, when NF- $\kappa$ B activation is impaired or when de novo protein synthesis is blocked, TNF $\alpha$ induces apoptotic cell death. ${ }^{7,15,16}$ Several targets of NF- $\kappa$ B, such as cFLIP ${ }^{13}$ clAP1/2 ${ }^{17}$ and in some models, antiapoptotic Bcl-2 family proteins such as $\mathrm{Bcl}-2^{18}, \mathrm{~A} 1^{19}$ or $\mathrm{Bcl}-\mathrm{xL}^{20}$ have been proposed as regulators of TNF $\alpha$-induced apoptosis. We have recently demonstrated that $\mathrm{Bcl}-\mathrm{xL}$ regulates $\mathrm{TNF} \alpha$-induced cell death, independently of NF- $k$ B or CFLIP. ${ }^{15}$ However, the mechanisms through which inhibition of $\mathrm{NF}-\kappa \mathrm{B}$ or cFLIP

${ }^{1}$ Cell Signaling and Apoptosis Group, Fundació Institut de recerca de l'Hospital Universitari de la Vall d'Hebron, Edifici Collserola, Laboratori 203, Passeig Vall d'Hebron 119-129, 08035 Barcelona, Spain; ${ }^{2}$ Institut de Neurociències, Departament de Bioquímica i Biologia Molecular, Facultat de Medicina, Universitat Autònoma de Barcelona, Campus de Bellaterra (Edifici M), Bellaterra, Spain; ${ }^{3}$ Centro de Investigación Biomédica en Red sobre Enfermedades Neurodegenerativas (CIBERNED), Spain and ${ }^{4}$ Laboratoris Clinics, Hospital Universitari Vall d'Hebron, Passeig Vall d'Hebron 119-129, Barcelona, Spain

*Corresponding author: RS Moubarak or Joan X Comella, Cell Signaling and Apoptosis Group, Fundació Institut de recerca de l'Hospital Universitari de la Vall d'Hebron, Edifici Collserola, Laboratori 203, Passeig Vall d'Hebron 119-129, E-08035 Barcelona, Spain. Tel: + 34934893807 ; Fax: +34 392746708 ; E-mail: rana.moubarak@vhir.org or joan.comella@vhir.org

${ }^{5}$ Present adress: Inflammation Laboratory, Instituto Gulbenkian de Ciência, Oeiras, Portugal.

Keywords: apoptosis; TNF $\alpha$; NF- $\kappa$ B; FLIP-L; ERK/MAPK

Abbreviations: DR, death receptor; TNF $\alpha$, tumor necrosis factor- $\alpha$; TNFR1, tumor necrosis factor receptor-1; DISC, death-inducing signaling complex; MAPK/ERK, mitogen-activated protein kinases/extracellular signal-regulated kinases; FLIP-L, FLICE-like inhibitory protein long form; NF- $\kappa$ B, nuclear factor-kappa B; JNK, jun nuclear kinase

Received 27.11.12; revised 02.1.13; accepted 09.1.13; Edited by G Raschella' 
sensitizes cells to TNF $\alpha$-induced apoptosis remain largely unknown. FLIP-L protects from DR-induced apoptosis in a wide range of cellular models. ${ }^{21-23}$ While the antiapoptotic role of FLIP-L is well established in the immune system, ${ }^{24-26}$ only a couple of reports have shown that FLIP-L controls embryonic motoneurons apoptosis during development ${ }^{27}$ and protects neurons against in vivo ischemia and in vitro glucose deprivation-induced cell death. ${ }^{28}$ We have recently established that FLIP-L is crucial for neurotrophin-induced neurite outgrowth through its interaction with Trk receptors, inducing the activation of both $\mathrm{NF}-\kappa \mathrm{B}$ and mitogen-activated protein kinases/extracellular signal-regulated kinases (MAPK/ERK) pathways. ${ }^{29}$ We also demonstrated that FLIP-L function in neurotrophin-induced differentiation is independent from its antiapoptotic role. However, the relevance of the MAPK/ERK and NF- $\kappa$ B pathways in the antiapoptotic function of FLIP-L in the nervous system has never been addressed before. It has been suggested that DRs can also induce activation of MAPK/ ERK pathway and jun nuclear kinase (JNK), ${ }^{30-33}$ even though the mediators of this activation and its biological role remain controversial. Therefore, we sought to determine the role of FLIP-L in DR-induced survival and apoptotic pathway.

We show here that TNF $\alpha$ treatment induces apoptosis when either NF- $\kappa \mathrm{B}$ or MAPK/ERK pathway is blocked. Otherwise, $\mathrm{TNF} \alpha$ treatment induces the activation of the MAPK/ERK pathway that depends on the specific regulation of FLIP-L transcription by NF- $\kappa$ B. FLIP-L interacts with Raf-1 and induces the activation of MAPK/ERK that is due to Raf-1 kinase activation but not Ras activation. We further demonstrate that MAPK/ERK is an important regulator of TNF $\alpha$-induced cell death in a neuronal cell model, as rescuing its activation by a constitutively active form of MEK or NGF treatment protects from TNF $\alpha$-induced apoptosis. Finally, we point out the relevance of the JNK pathway and the proapoptotic BH3-only protein Bim in TNF $\alpha$-induced apoptotic response. Therefore, our findings suggest a novel mechanism for TNF $\alpha$-mediated neuroprotection versus cell death mechanism.

\section{Results}

NF- $\kappa$ B inhibition sensitizes PC12 cells to the apoptotic effect of TNF $\alpha$. NF- $\kappa$ B has been postulated, in many cellular models, to be the main regulator of the antiapoptotic response triggered by TNFR1 activation. To confirm that NF- $\kappa \mathrm{B}$ inhibition sensitizes PC12 cells to apoptosis induced by TNF $\alpha$, we stably transfected PC12 cells with an empty plasmid or a non-degradable form of human IkB $\alpha$ (S32A/ S36A), named SR-lkB $\alpha$, which blocks TNF $\alpha$-induced NF- $\kappa$ B activation. Cells were untreated or treated with $\mathrm{TNF} \alpha$ for different time points and executioner caspase activity was analyzed (Figure 1a), showing a gradual increase in caspase activity induced by $\mathrm{TNF} \alpha$ that was significant only when $\mathrm{NF}-\kappa \mathrm{B}$ activation has been blocked. As maximal caspase activation is reached after $24 \mathrm{~h}$ of TNF $\alpha$ treatment, cell death was determined by counting of apoptotic nuclei at the same time point (Figure 1b), revealing that PC12 cells overexpressing the super-repressor $\left(\mathrm{SR}-\mathrm{I}_{\kappa} \mathrm{B} \alpha\right)$ plasmid and treated with TNF $\alpha$ undergo apoptosis when compared with cells expressing the control plasmid (Neo). Moreover, TNF $\alpha$ - induced $3^{\prime}-\mathrm{OH}$ DNA labeled ends (TUNEL) is only seen in $\mathrm{PC} 12$ cells transfected with the SR-I $\kappa \mathrm{B} \alpha$ (Figure 1c). Efficient blockade of NF- $\kappa \mathrm{B}$ activation is controlled by the inhibition of the nuclear translocation of p65 in SR-IkB $\alpha$-transfected cells treated with TNF $\alpha$ for 15 min (Figures $1 d$ and 1e), as well as the accurate expression of the SR-IkB $\alpha$ mutant form of human $\mathrm{lkB} \alpha$ by western blotting (Figure 1f).

\section{NF- $\kappa$ B-induced FLIP-L expression controls MAPK/ERK} activation. Although it has been previously reported that DRs can activate the MAPK/ERK pathway, the mechanism and relevance of DR-induced MAPK activation in the nervous system remain unknown..$^{9,30,34,35}$ In order to assess the activation of MAPK/ERK by TNF $\alpha$, we first analyzed the timecourse and dose-dependence of ERK1/2 activation by TNF $\alpha$ treatment. TNF $\alpha$ induces a rapid phosphorylation of ERK1/2 that is maximal at $5 \mathrm{~min}$ and decreases later on until it is almost undetectable after $60 \mathrm{~min}$ of treatment (Figure 2a). Moreover, increasing concentrations of TNF $\alpha$ have the same effect on TNF $\alpha$-induced MAPK/ERK activation after $5 \mathrm{~min}$ of treatment (Figure 2b). In the immune system, it has been shown that MAPK activation by Fas treatment is dependent on FLIP-L. ${ }^{24}$ As FLIP-L is one of the genes regulated by $\mathrm{NF}-\kappa \mathrm{B}$ in many cells, we explored the putative role of $\mathrm{NF}-\kappa \mathrm{B}$ in FLIP-L expression and the role of FLIP-L in MAPK/ERK activation. Transient transfection of PC12 cells with an empty pcDNA3 plasmid (Neo) or with the SR-IkB $\alpha$ shows that NF- $\kappa \mathrm{B}$ regulates FLIP-L expression as it decreases over time until it is almost undetectable after 2 days of $\mathrm{SR}-\mathrm{I}_{\kappa} \mathrm{B} \alpha$ transfection. However, the expression of $\mathrm{Bcl}-\mathrm{xL}$ remains unchanged (Figure 2c). Moreover, we assessed the contribution of $\mathrm{NF}-\kappa \mathrm{B}$ activation to the MAPK/ERK activation induced by $\mathrm{TNF} \alpha$ stimulation in PC12 cells transfected with the SR-I $\kappa \mathrm{B} \alpha$ plasmid. By contrast with empty-vector transfected cells, SR-I $\kappa \mathrm{B} \alpha$-transfected cells do not show any phosphorylation of ERK1/2 (Figure 2d). This result indicates that TNF $\alpha$-mediated activation of ERK1/2 is dependent on $\mathrm{NF}-\kappa \mathrm{B}$ activation. We further analyzed the relevance of FLIP-L in the TNF $\alpha$-induced activation of the MAPK/ERK pathway. PC12 cells were infected with a FLIP-L overexpression lentivirus and, after $48 \mathrm{~h}$ of lentiviral infection, cells were treated with TNF $\alpha$ for the indicated time points and activation of MAPK/ERK pathway was analyzed (Figure 2e). Our results show that in cells overexpressing FLIP-L, TNF $\alpha$ induces a more prolonged ERK1/2 phosphorylation when compared with control cells infected with an empty plasmid. Finally, in order to validate the relevance of FLIP-L as a mediator of ERK1/2 phosphorylation induced by $T N F \alpha$, we carried out a lentiviral-based knockdown of FLIP-L (shFLIP-L). Three days after infection, cells exhibited a strong reduction in FLIP-L expression and FLIP-L knockdown prevents ERK1/2 phosphorylation (Figure 2f). Altogether, these results confirm that NF- $\kappa$ B-regulated FLIP-L has a key role in MAPK/ERK activation induced by $\operatorname{TNF} \alpha$.

TNF $\alpha$ induces FLIP-L-dependent Raf-1 activation. As we demonstrate here that FLIP-L is necessary for TNF $\alpha$-induced MAPK activation, we further analyzed the upstream step that is critical for this event. ERK $1 / 2$ activation is frequently a result of Ras activation, which recruits to the membrane the 

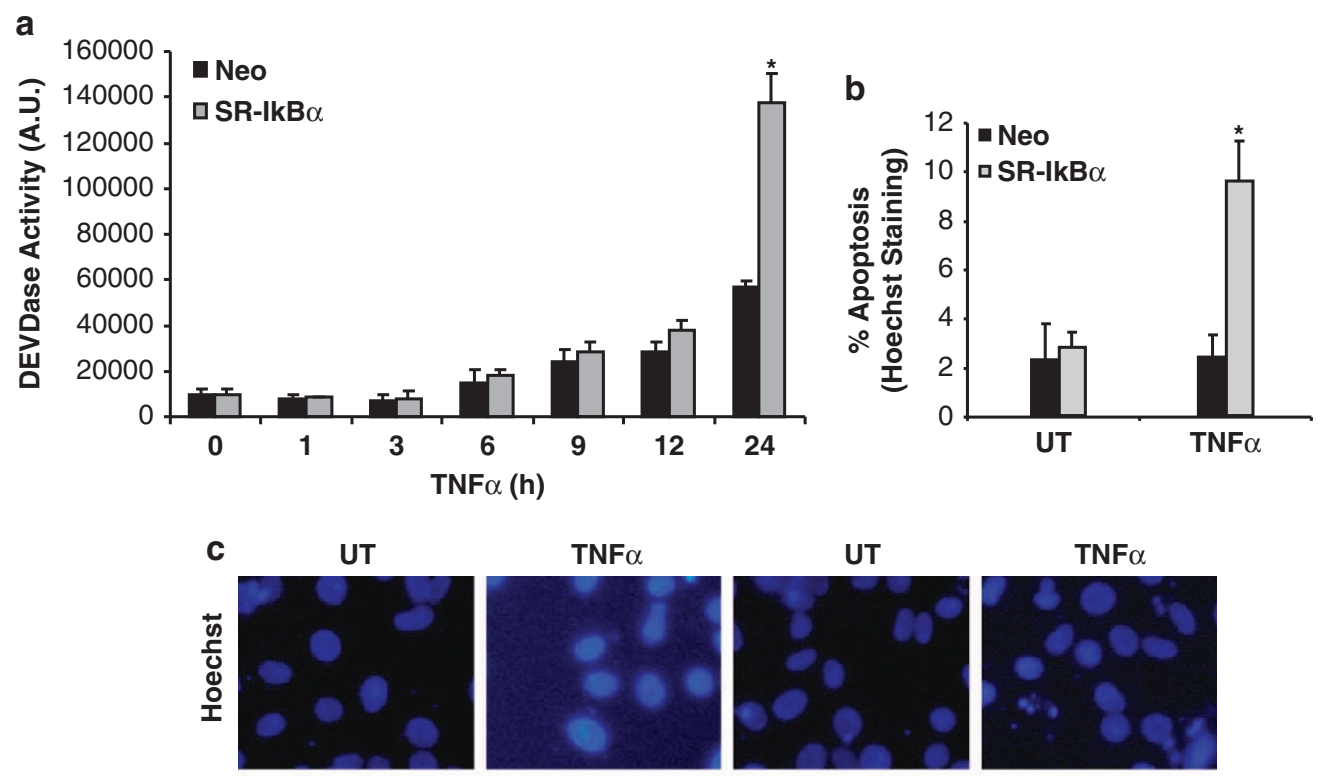

$\mathrm{TNF} \alpha$

UT
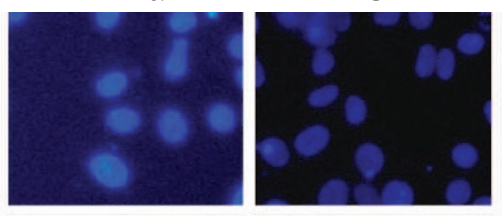

$\operatorname{TNF} \alpha$
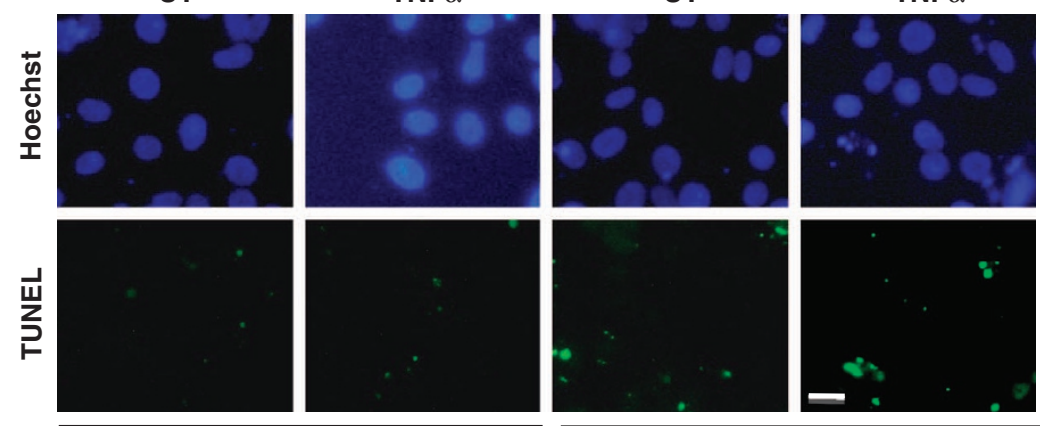

SR-IkB $\alpha$

d
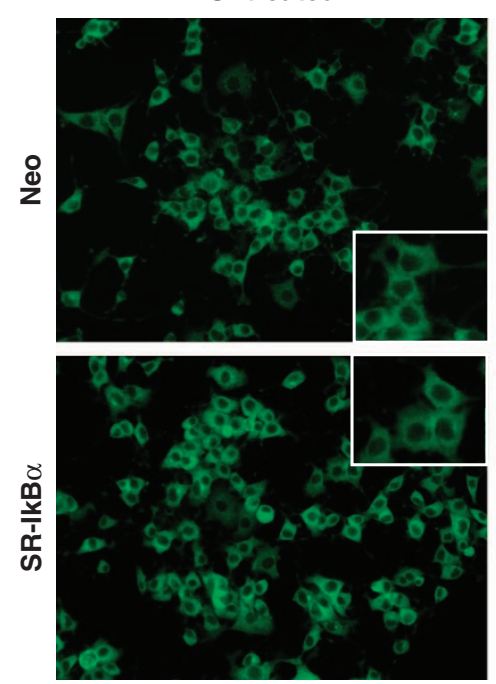

TNF $\alpha$
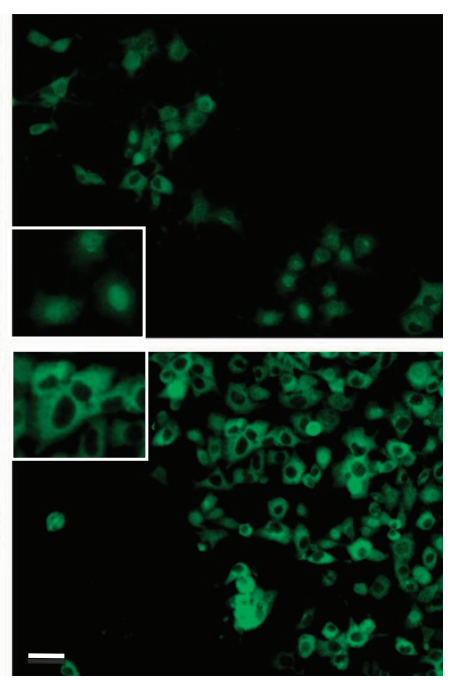

e 60

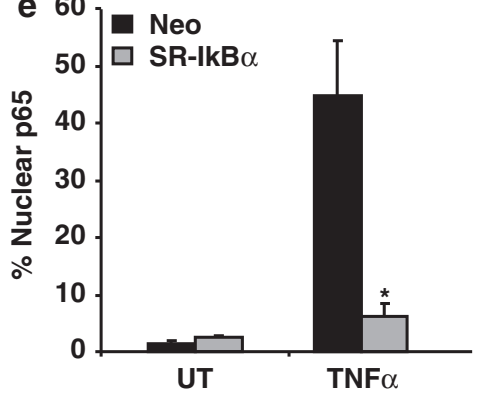

f

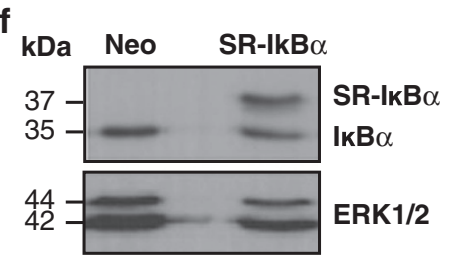

Figure 1 NF- $\kappa$ B pathway inhibition renders PC12 cells sensitive to TNF $\alpha$-induced apoptosis. (a) PC12 cells stably transfected with an empty (Neo) or with SR-I $\kappa$ B $\alpha$ plasmid were treated for the indicated time points with $100 \mathrm{ng} / \mathrm{ml}$ of TNF $\alpha$ and a caspase-3-like activity assay was performed using Ac-DEVD-afc fluorogenic substrate. Significant differences are indicated ( ${ }^{*} P<0.001, t$-test). (b) PC12 cells stably expressing an empty plasmid (Neo) or SR- $\mid \kappa B \alpha$ were left untreated or treated with $100 \mathrm{ng} / \mathrm{ml}$ of TNF $\alpha$ for $24 \mathrm{~h}$. Apoptotic cell death was quantified by direct counting of condensed nuclei stained with Hoechst 33258 . Significant differences are indicated ( ${ }^{*} P<0.01, t$-test). (c) Cells were treated as in $\mathbf{b}$ and TUNEL assay was performed, with costaining with Hoechst 33258 . Scale bar, $10 \mu \mathrm{m}$. (d) Cells were left untreated or treated with $100 \mathrm{ng} / \mathrm{ml}$ of $\mathrm{TNF} \alpha$ for $15 \mathrm{~min}$. Immunocytochemistry was performed to detect the nuclear translocation of the p65 subunit of NF- $\kappa \mathrm{B}$ and representative images of three independent experiments show nuclear translocation of $\mathrm{p} 65$. Scale bar, $5 \mu \mathrm{m}$. (e) The percentage of cells displaying nuclear translocation of p65 was determined. Significant differences are indicated ( ${ }^{*} P<0.01$, $t$-test). (f) PC12 cells were stably transfected with an empty plasmid (Neo) or SR- $\left.\right|_{\kappa} B \alpha$. The expression of the human mutated form of $I_{\kappa} B \alpha$ after $S R-I_{\kappa} B \alpha$ plasmid transfection was validated by western blot, leading to a higher band. Equal loading was confirmed by reblotting with an anti-ERK1/2 antibody. For all the histograms, error bars indicate S.D. of three independent experiments

MAPKKK Raf-1, leading to the activation of the MAPKK MEK1 that in turn phosphorylates ERK1/2. ${ }^{36}$ We show that $\mathrm{TNF} \alpha$ treatment, unlike NGF treatment, does not activate
Ras, the protein upstream Raf-1 in the MAPK pathway, as seen by pull-down of active Ras (Figure 3a). However, a Raf-1 kinase assay performed in PC12 cells treated with 
a
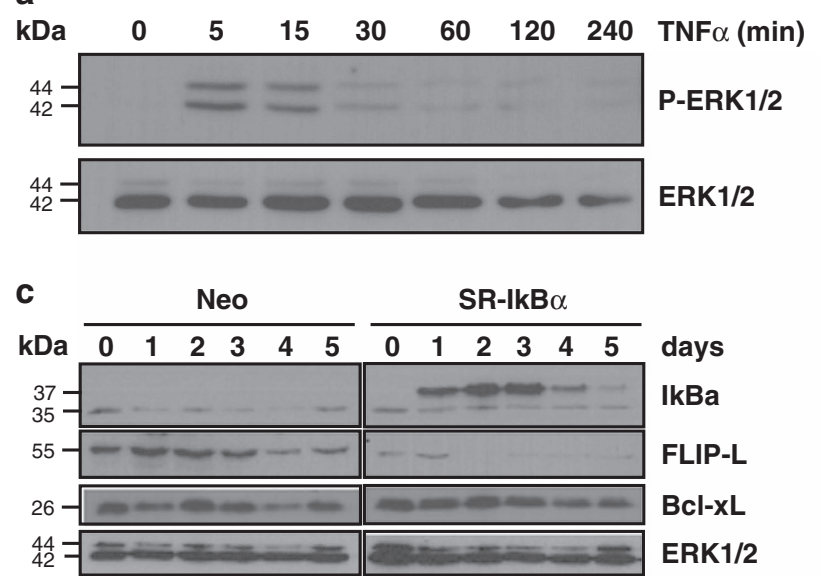

b

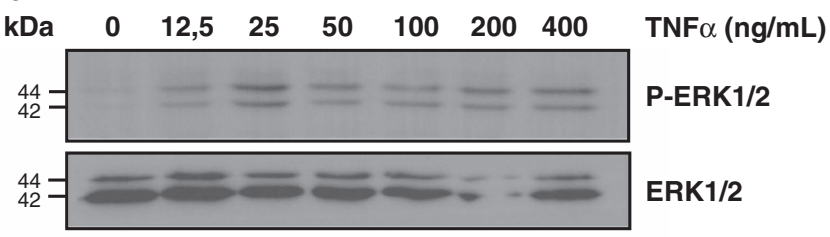

d

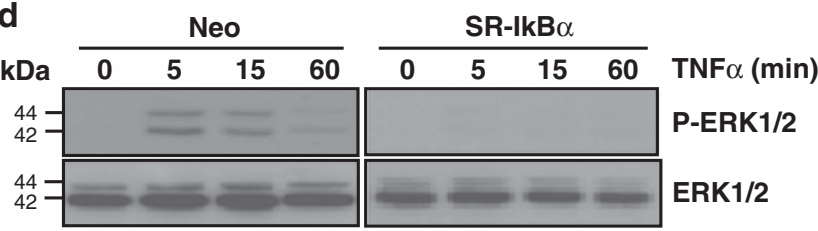

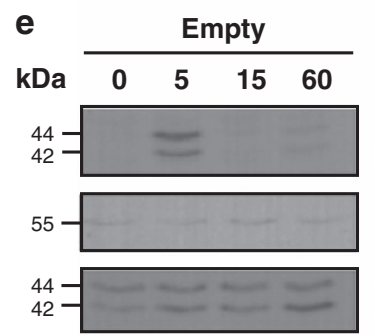

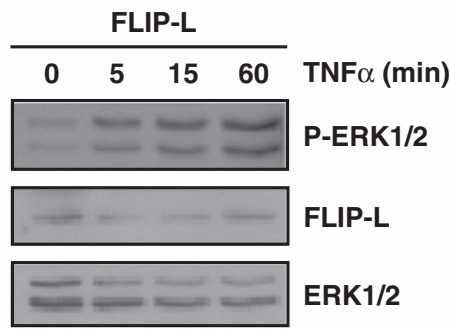

f
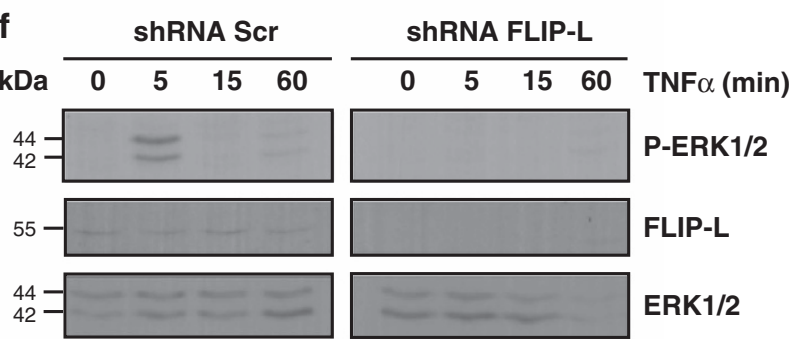

Figure 2 FLIP-L controls TNF $\alpha$-induced activation of MAPK/ERK pathway under the regulation of NF- $k B$. (a) PC12 cells previously serum-deprived for $12 \mathrm{~h}$ were left untreated or treated for the indicated time points with $100 \mathrm{ng} / \mathrm{ml}$ of TNF $\alpha$. Total cell lysates were analyzed by western blotting using an anti-P-ERK1/2 antibody. (b) Serumdeprived PC12 cells were left untreated or treated with increasing concentrations of TNF $\alpha$ for 5 min and MAPK/ERK activation was assessed as in a. (c) Expression of $I_{\kappa} B \alpha$, FLIP-L and Bcl-xL in PC12 cells transiently transfected with an empty plasmid (Neo) or SR-I $\kappa$ B $\alpha$ plasmid was detected by western blot at different days after transfection (days). (d) PC12 cells were stably transfected with an empty (Neo) or SR-I $\kappa$ B $\alpha$ plasmid, serum-deprived then left untreated or treated with $100 \mathrm{ng} / \mathrm{ml}$ of TNF $\alpha$ for the indicated time points. Total cell lysates were analyzed by western blot using an anti-P-ERK1/2 antibody. (e) PC12 cells were transduced with Empty or FLIP-L overexpression lentiviruses, serum-deprived 2 days post-transduction, then left untreated or treated with $100 \mathrm{ng} / \mathrm{ml}$ of TNF $\alpha$ for the indicated time points. Total cell lysates were analyzed by immunoblotting using an anti-P-ERK1/2 antibody. An anti-FLIP antibody was used to control efficiency of transduction. (f) PC12 cells were transduced with scrambled sequence (shRNA Scr) or shRNA against FLIP-L (shRNA FLIP-L) lentiviruses, serum-deprived 3 days post-transduction, then left untreated or treated with $100 \mathrm{ng} / \mathrm{ml}$ of TNF $\alpha$ for the indicated time points. Total cell lysates were analyzed by immunoblotting with a specific antibody against P-ERK $1 / 2$. FLIP-L knockdown efficiency was assessed using the anti-FLIP antibody. In all panels, equal loading was confirmed by reblotting the membranes with an anti-ERK1/2 antibody

TNF $\alpha$ or NGF for 5 min reveals Raf- 1 activation (Figure 3b). Moreover, we show that TNF $\alpha$-induced Raf-1 activation, as well as ERK1/2 phosphorylation depends on NF- $k$ B activity, because Raf-1 is inactive in SR-IkB-transfected cells treated with TNF $\alpha$ (Figure 3c). In the same manner, FLIP-L knockdown abrogates TNF $\alpha$-induced Raf- 1 activation and subsequent ERK1/2 activation (Figure 3d), which demonstrates a direct role of FLIP-L in Raf-1 activation and subsequent ERK1/2 phosphorylation. Additionally, we assessed Raf-1 activation by its recruitment to the membrane, as this has been shown to be a main step for Raf-1 activation. A subfractionation analysis reveals that Raf- 1 is clearly enriched in membrane fractions in cells treated with TNF $\alpha$ for $15 \mathrm{~min}$, in comparison with a treatment of $5 \mathrm{~min}$ or untreated cells (Figure $3 e$ ). We also show that most of the phosphorylated ERK $1 / 2$ is located in the cytosol (Figure 3e). As it is well established, we also demonstrate that Raf-1 activation is necessary for MAPK/ERK pathway activation, as Raf-1 knockdown significantly impairs TNF $\alpha$-induced ERK $1 / 2$ phosphorylation (Figure 3f). Finally, we show that Raf-1 and FLIP-L interact by immunoprecipitation of FLIP-L in PC12 cells transfected with HA-tagged FLIP-L and/or Raf-1
(Figure $3 \mathrm{~g}$ ), as a suggestion of a structural basis for Raf-1 activation. Taken together, these results allow us to conclude that FLIP-L is able to activate Raf- 1 by an alternative mechanism to the classical Ras activation.

NF- $\kappa$ B and MAPK/ERK inhibition are equivalent for sensitization of PC12 cells to the apoptotic effect of $T N F \alpha$. As shown in Figure 1, when NF- $k B$ pathway is blocked, TNF $\alpha$ induces apoptosis. As we have linked NF- $\kappa \mathrm{B}$ activation and FLIP-L regulation to MAPK/ERK activation, we further investigated whether inhibition of MAPK/ERK is equivalent to NF- $\kappa \mathrm{B}$ blockade in terms of sensitivity to TNF $\alpha$-induced apoptosis. To this end, we analyzed the effects of TNF $\alpha$ in presence of the MEK1 inhibitor PD98059. Cells pretreated with PD98059 and treated with TNF $\alpha$ show a decrease in cell viability when compared with untreated cells or cells treated with TNF $\alpha$ or PD98059 alone (Figure 4a). Furthermore, a DEVDase activity assay reveals that TNF $\alpha$ significantly induces caspase activation upon MEK1 inhibition, when compared with an untreated control or the single TNF $\alpha$ or PD98059 treatments (Figure 4b). Finally, apoptotic cell death was evaluated by quantification of condensed 


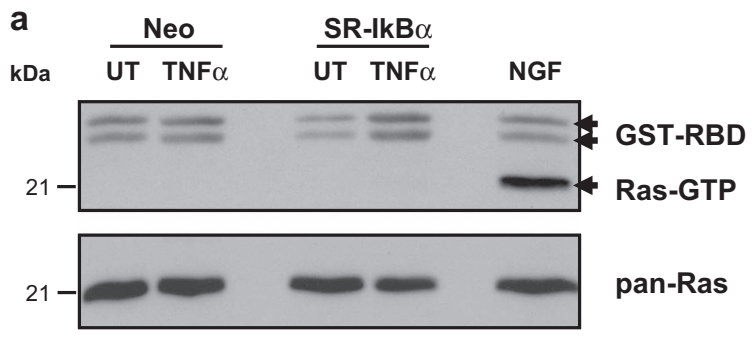

C
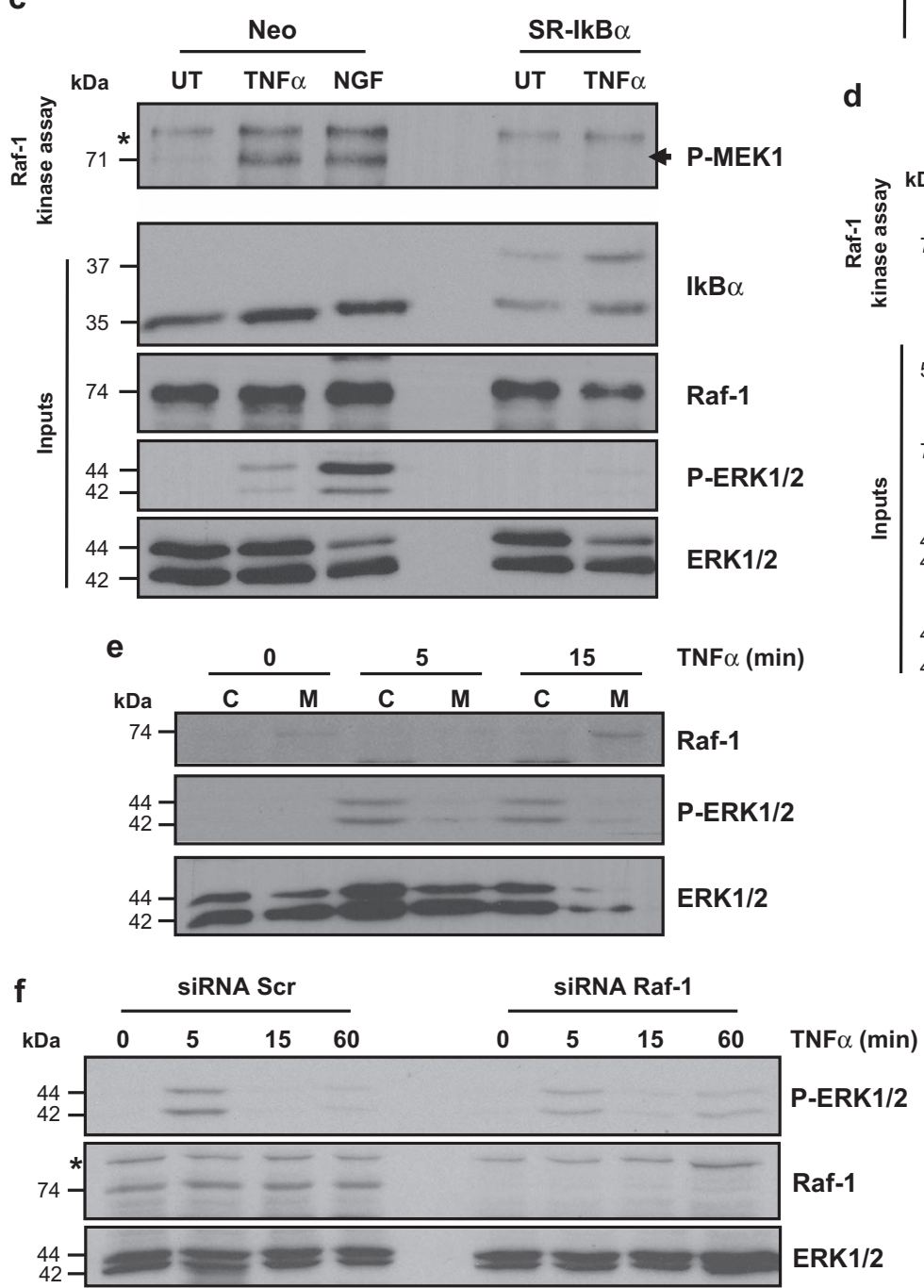
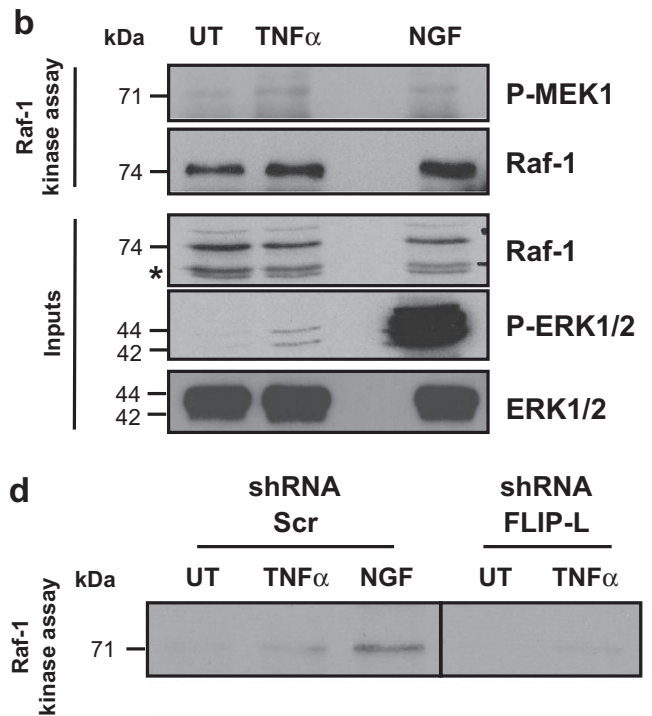

P-MEK1

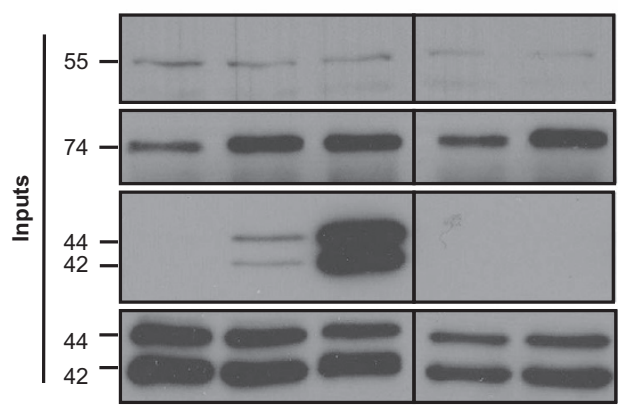

FLIP-L

Raf-1

P-ERK1/2

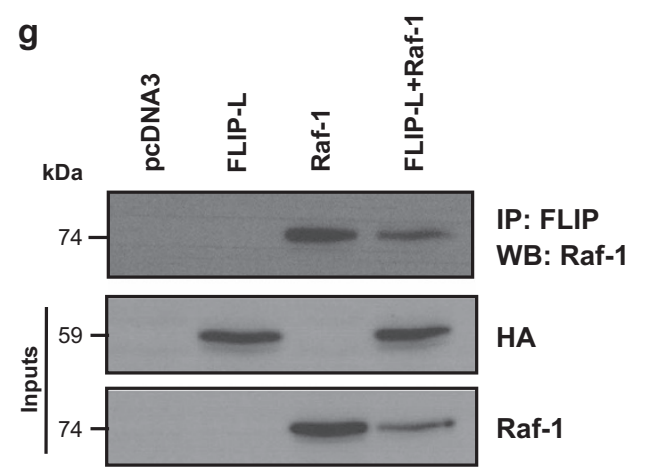

Figure 3 TNF $\alpha$ induces ERK1/2 activation in a Ras-independent manner and induces Raf-1 kinase activity in a FLIP-L-dependent manner. (a) Serum-deprived PC12 cells were treated with $100 \mathrm{ng} / \mathrm{ml}$ of TNF $\alpha$ or NGF for $5 \mathrm{~min}$, and activated Ras was pulled down using Raf-RBD conjugated agarose beads. GTP-bound Ras was detected by western blot using an anti-pan-Ras antibody. (b) Endogenous Raf-1 was immunoprecipitated from PC12 cells treated with TNF $\alpha$ or NGF and immunoprecipitates were incubated with recombinant MEK and ATP in vitro in order to detect Raf-1 kinase activity. Western blot analysis was performed for Raf-1 and P-MEK1. Inputs were blotted using anti-Raf-1, anti-P-ERK1/2, and anti-ERK1/2 antibody as a loading control. (c) Raf- 1 kinase activity was assessed as in $\mathbf{b}$, in PC12 cells transfected with Neo or SR- $\mid \kappa B \alpha$, (d) or after 3 days of PC12 transduction with scrambled sequence (shRNA Scr) or shRNA against FLIP-L (shRNA FLIP-L) lentiviruses. Black lines indicate that intervening lanes have been spliced. (e) Serum-deprived PC12 cells were treated with TNF $\alpha$ for the indicated times prior harvesting and subcellular fractionation. Lysates corresponding to cytosolic (C) and membrane fractions (M) were resolved by SDS-PAGE and Raf-1 subcellular localization was assessed by western blot using an anti-Raf-1 antibody. ERK1/2 phosphorylation was also detected to control MAPK/ERK activation following TNF $\alpha$ stimulation. (f) PC12 cells were transfected with siRNA targeting Raf-1 or a scrambled sequence. Three days after transfection, cells were treated with TNF $\alpha$ for the indicated time points and western blot was performed to detect P-ERK1/2, Raf-1 and total ERK $1 /$ 2 as loading control. (g) PC12 cells were transfected with pcDNA3-HA-FLIP-L, pcDNA3-Raf-1 or both plasmids. Cells were harvested $24 \mathrm{~h}$ later and FLIP-L was immunoprecipitated using a specific anti-FLIP antibody prior western blot using anti-Raf-1 antibody. Transfection efficiency of both plasmids was checked in the inputs. The asterisk indicates nonspecific bands 

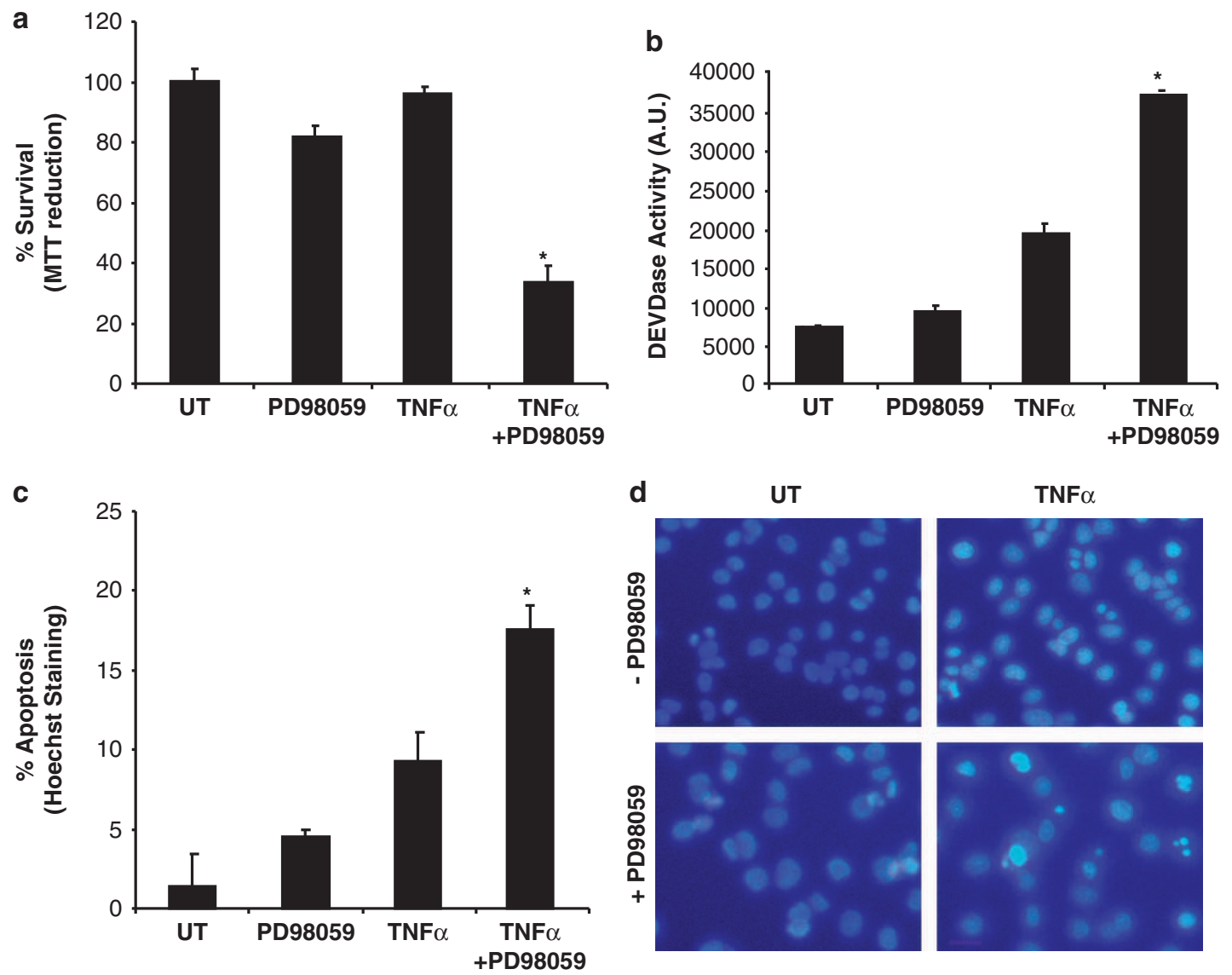

Figure 4 MAPK/ERK activation protects from apoptotic cell death induced by TNF $\alpha$. (a) PC12 cells pretreated or not with $30 \mu \mathrm{M}$ of PD98059 were left untreated or treated with TNF $\alpha$ and/or PD98059 for $24 \mathrm{~h}$ before MTT reduction assay was performed. (b) Cells were treated as in a before caspase-3-like activity was measured using the AcDEVD-afc fluorogenic substrate, (c) and apoptotic cell death quantified by direct counting of condensed nuclei using Hoechst 33258 staining. Significant differences are indicated $\left({ }^{*} P<0.001, t\right.$-test). Error bars indicate S.D. of three independent experiments. (d) Representative images of Hoechst 33258-stained nuclei are shown. Scale bar, $10 \mu \mathrm{m}$

nuclei stained with Hoechst 33258 (Figure 4c). A higher percentage of apoptotic cell death is noticeable in cells cotreated with TNF $\alpha$ and PD98059 (Figure 4c), and the level of apoptotic cell death reached is similar to the one observed in cells stably transfected with $\mathrm{SR}-\mathrm{I}_{\kappa} \mathrm{B} \alpha$ and treated with $\mathrm{TNF} \alpha$ alone (Figure 1b). Figure $4 \mathrm{~d}$ shows representative images of nuclear staining with Hoechst 33258 for all treatment conditions. These results allow us to conclude that the inhibition of the MAPK pathway, as well as NF- $\kappa$ B pathway abrogation, sensitizes cells to the pro-apoptotic function of TNF $\alpha$.

MAPK/ERK activation is essential in the cell survival pathway elicited after TNF $\alpha$ treatment. To further assess the link between NF- $\kappa \mathrm{B}$ and MAPK/ERK pathways, we checked whether sustained activation of the MAPK pathway in SR-I $\|_{k} \mathrm{~B}$-expressing cells would protect them from $\mathrm{TNF} \alpha$-induced cell death. Neo- or SR-I $\kappa \mathrm{B} \alpha$-expressing PC12 cells were transfected with a plasmid encoding the constitutively active form of MEK (MEK-CA) or pcDNA3. Figure 5a shows a significant increase in DEVDase activity after $24 \mathrm{~h}$ of $\mathrm{TNF} \alpha$ treatment in cells expressing $\mathrm{SR}-\mathrm{I}_{\kappa} \mathrm{B} \alpha$, which is restored to control levels when MEK-CA is coexpressed with the $I_{\kappa} \mathrm{B} \alpha$ mutant. In the same sense, apoptotic cell death was quantified by chromatin condensation and we show that the TNF $\alpha$ induced cell death in SR-I $\kappa$ B-expressing cells is significantly reduced to the same level as untreated controls, when both SR-I $\kappa \mathrm{B} \alpha$ and MEK-CA are coexpressed (Figure 5b). PC12 cells transfected with the MEK-CA show constitutive phosphorylation of ERK $1 / 2$ as compared with Neo-transfected cells (Figure 5c). Alternatively, to demonstrate that the activation of MAPK/ERK is essential for neuroprotection upon TNF $\alpha$ treatment, we treated stably transfected $\mathrm{Neo}$ and SR-lkB PC12 cells with TNF $\alpha$, in the presence or not of $100 \mathrm{ng} / \mathrm{ml}$ of $\mathrm{NGF}$ for $24 \mathrm{~h}$. NGF is a neurotrophin that activates MAPK/ERK through tyrosine kinase receptors by a classical Ras-dependent manner (Figure 3a). As evidenced in Figure 5d, TNF $\alpha$ treatment induces apoptosis when the NF- $\kappa \mathrm{B}$ pathway is blocked, as compared with Neo control cells. Interestingly, cotreatment with NGF protects these cells from apoptosis induced by $\mathrm{TNF} \alpha$, even though the NF- $\kappa \mathrm{B}$ pathway is blocked (Figures $5 \mathrm{~d}$ and $5 \mathrm{e}$ ). These results support that the MAPK/ ERK pathway activation is necessary and sufficient for the pro-survival effects of TNF $\alpha$. 

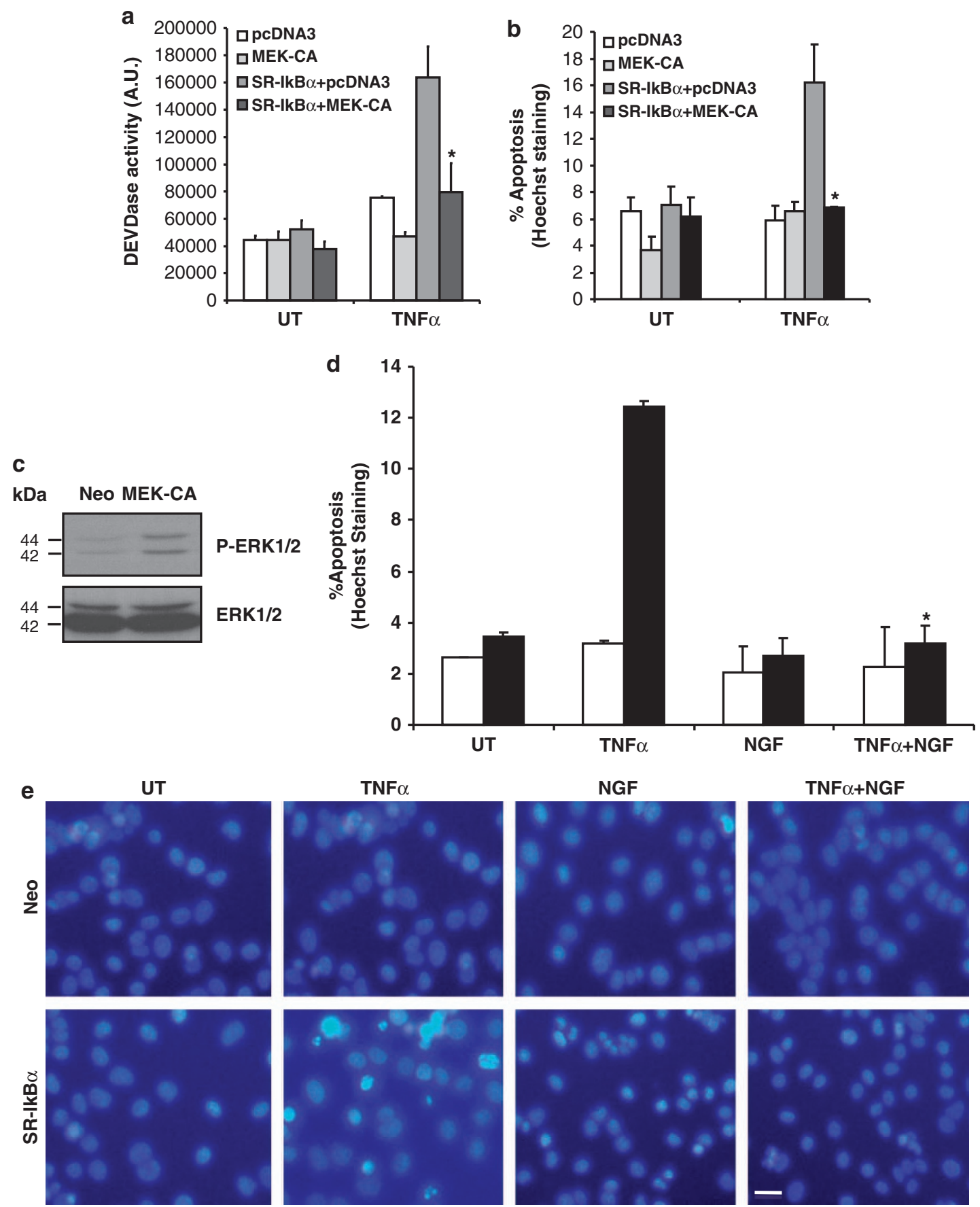

Figure 5 Constitutive activation of MAPK/ERK pathway or NGF treatment protects SR-I $\kappa$ B $\alpha$-transfected PC12 cells from TNF $\alpha$-induced apoptosis. (a) PC12 cells stably transfected with an empty plasmid (Neo) or SR-I $\kappa$ B $\alpha$ were transiently transfected with or without a plasmid carrying a constitutively active form of MEK (MEK-CA). Twenty-four hours after transfection, cells were left untreated or treated with $100 \mathrm{ng} / \mathrm{ml}$ of TNF $\alpha$ for $24 \mathrm{~h}$. Caspase-3-like (DEVDase) activity was measured using the Ac-DEVD-afc fluorogenic substrate. Significant differences are indicated $\left({ }^{*} P<0.01, t\right.$-test). (b) Percentage of cell death was measured by counting apoptotic nuclei after Hoechst 33258 staining. Significant differences are indicated $\left({ }^{*} P<0.01, t\right.$-test). (c) Cell lysates of Neo- or MEK-CA-transfected cells were immunoblotted using anti-P-ERK1/2 antibody. Note that ERK $1 / 2$ is basally phosphorylated in untreated cells. Equal loading was confirmed by reblotting with an anti-ERK1/2 antibody. (d) PC12 cells stably transfected with an empty plasmid (Neo) or SR-I $\mathrm{B}$ B $\alpha$ were treated with $100 \mathrm{ng} / \mathrm{ml}$ of TNF $\alpha$ and/or NGF for $24 \mathrm{~h}$. Apoptotic cell death was assessed by direct counting of condensed nuclei stained with Hoechst 33258. Significant difference between SR-I $\kappa B \alpha$-transfected and TNF $\alpha$ - or TNF $\alpha+$ NGF-treated cells is indicated ( ${ }^{\star} P<0.01, t$-test). (e) Representative pictures of Hoechst 33258-stained cells treated as in $\mathbf{d}$ are shown. Scale bar, $10 \mu \mathrm{m}$. For all the histograms, error bars indicate S.D. of three independent experiments

Inhibition of NF- $\kappa$ B or MAPK/ERK sensitizes PC12 cells to TNF $\alpha$-induced apoptosis through the JNK pathway. It has been reported that TNF $\alpha$ might induce apoptosis through the activation of c-JNK. ${ }^{31,37-39}$ The BH3-only protein Bim has been identified as a key mediator of apoptosis acting downstream of JNK via the intrinsic pathway in several models, ${ }^{40}$ including neuronal cells. ${ }^{41,42}$ In order to determine if the JNK pathway is implicated in the TNF $\alpha$-induced cell 
death when the NF- $\kappa$ B pathway is blocked, empty-vector or SR-I $\kappa \mathrm{B} \alpha$-transfected $\mathrm{PC} 12$ cells were treated with $\mathrm{TNF} \alpha$ and the activation of JNK1/2 and its downstream mediators of apoptosis was analyzed. As shown in Figure $6 \mathrm{a}, \mathrm{SR}-\mathrm{I}_{\kappa} \mathrm{B} \alpha-$ expressing PC12 cells show a significant and sustained increase in phosphorylated JNK1/2 levels (P-JNK1/2) after $24 \mathrm{~h}$ of $\mathrm{TNF} \alpha$ treatment, as compared with their respective empty-vector control. Moreover, the observed JNK1/2 activation correlates with an increase in the expression of the pro-apoptotic BH3-only protein Bim but not PUMA
(Figure 6a). The upregulation of Bim in SR-I $\kappa \mathrm{B} \alpha$-expressing PC12 cells treated with TNF $\alpha$ is dependent on the activation of the JNK pathway, as the pretreatment with the JNK1/2 inhibitor SP600125 followed by TNF $\alpha$ treatment completely inhibited both JNK1/2 phosphorylation and Bim upregulation (Figure $6 b$ ). In this case, the endogenous levels of Bim are restored to their basal level, as in Neo-transfected PC12 cells treated with $\mathrm{TNF} \alpha$ (Figure $6 \mathrm{~b}$, left panel). In order to link the activation status of JNK1/2 to the sensitization to TNF $\alpha$ induced apoptosis, stable Neo or SR-I $\kappa$ B $\alpha$-transfected PC12 a

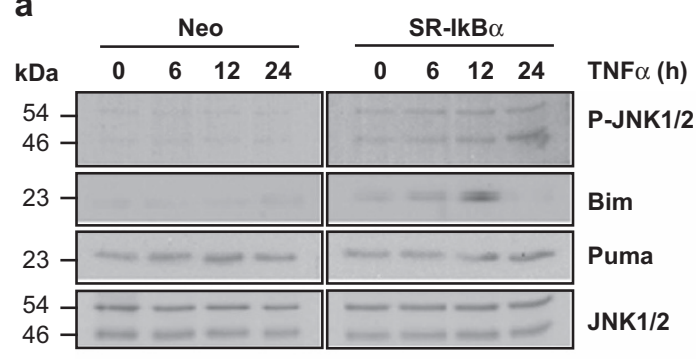

C b
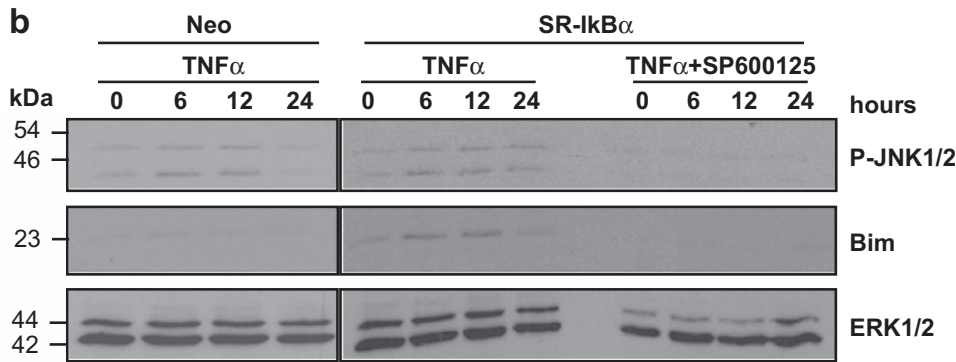

ERK1/2

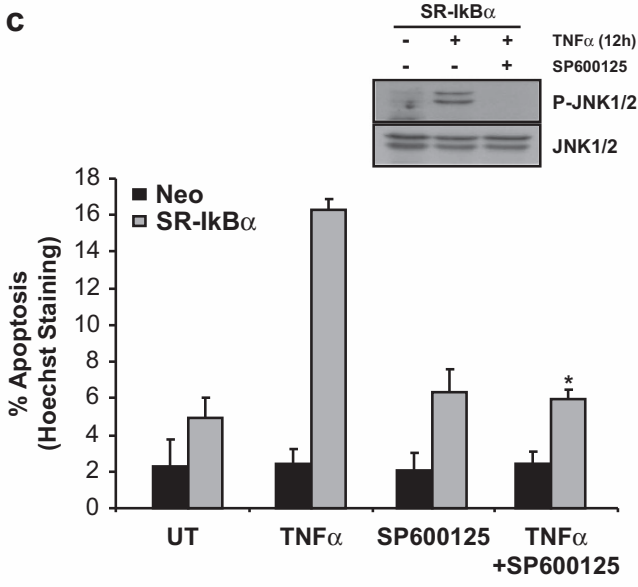

d
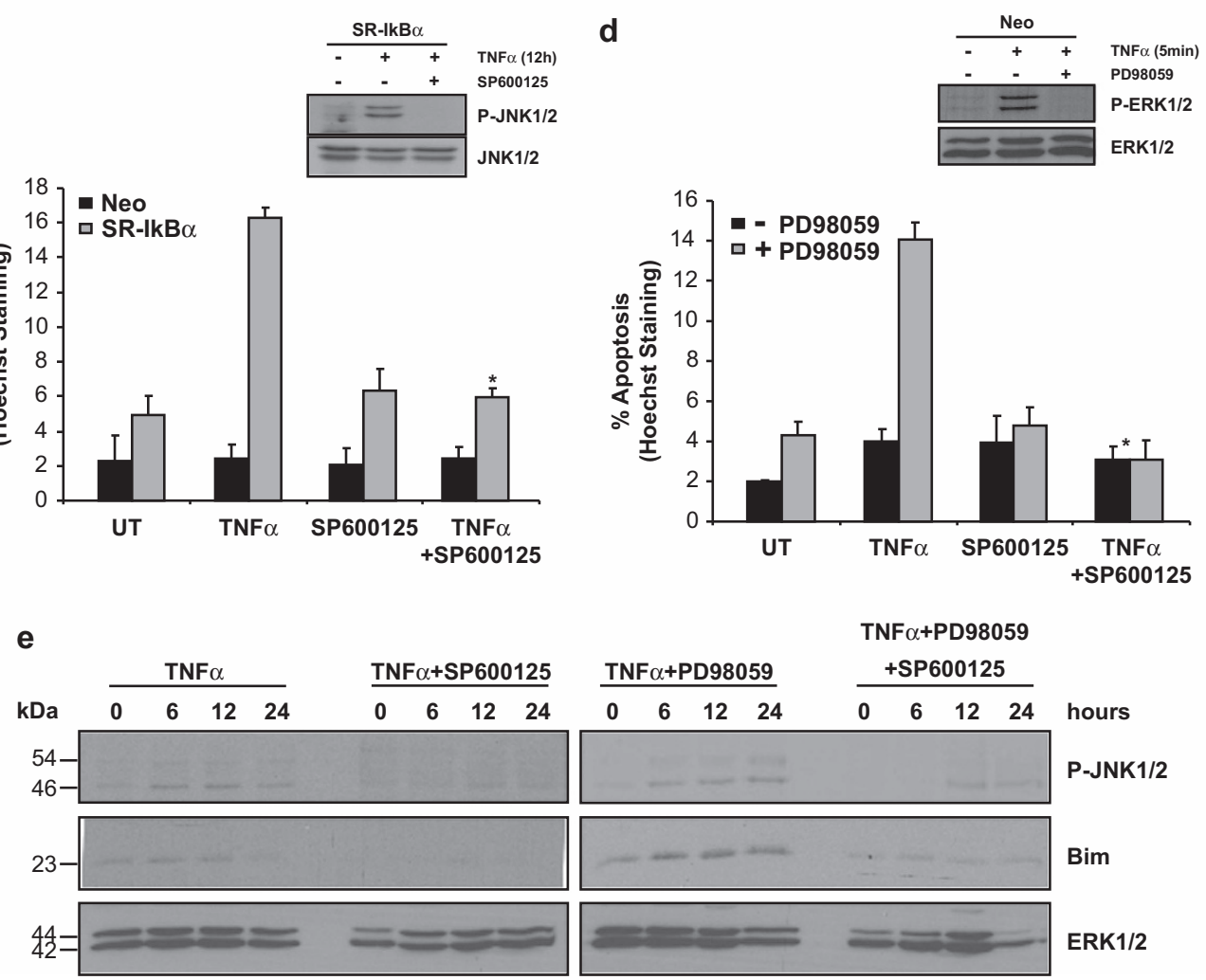

Figure $6 \mathrm{TNF} \alpha$ treatment upregulates Bim through the activation of JNK1/2 pathway. (a) PC12 cells stably expressing an empty (Neo) or SR-I $\mid \kappa \mathrm{B} \alpha$ plasmid were treated with $100 \mathrm{ng} / \mathrm{ml}$ of TNF $\alpha$ for the indicated time points. Total cell lysates were analyzed using specific anti-P-JNK1/2, anti-Bim and anti-Puma antibodies. A specific antibody against total JNK1/2 was used as a loading control. (b) PC12 cells stably transfected with an empty (Neo) or SR-I $\mid \mathrm{B} \alpha$ plasmid were treated with $100 \mathrm{ng} / \mathrm{ml}$ of TNF $\alpha$ or TNF $\alpha$ plus $10 \mu \mathrm{M}$ of the specific JNK inhibitor SP600125 for the indicated time points. Total cell lysates were analyzed using specific anti-P-JNK1/2, anti-Bim and anti-ERK1/2 antibodies. (c) Cells were pretreated or not with $10 \mu \mathrm{M}$ of SP600125 prior treatment with $100 \mathrm{ng} / \mathrm{ml}$ of TNF $\alpha$ and/or SP600125 for $24 \mathrm{~h}$. Apoptotic cell death was quantified by counting condensed nuclei stained with Hoechst 33258. Significant difference between SR-I $\kappa$ B $\alpha$-transfected and TNF $\alpha-o r$ TNF $\alpha+$ SP600125-treated cells is indicated $\left({ }^{*} P<0.01, t\right.$-test). Efficiency of the inhibitor was analyzed by western blot of P-JNK1/2 in SR-I $\kappa$ B $\alpha$-transfected cells treated with TNF $\alpha$ and/or SP600125 for $12 \mathrm{~h}$. (d) PC12 cells were pretreated or not with $30 \mu \mathrm{M}$ of PD98059 prior treatment with TNF $\alpha$ and/or SP600125 for $24 \mathrm{~h}$. Apoptotic cell death was quantified as in c. Significant differences are indicated $\left({ }^{*} P<0.001\right.$, $t$-test). Efficiency of the MEK1 inhibition was analyzed by western blot of P-ERK1/2 in cells treated with TNF $\alpha$ and/or PD98059 for $12 \mathrm{~h}$. (e) PC12 cells were pretreated or not with $30 \mu \mathrm{M}$ of PD98059 and/or SP600125 prior treatment with TNF $\alpha$ and/or PD98059 and/or SP600125 for the indicated time points. Total cell lysates were analyzed using specific antibodies against P-JNK1/2, Bim and ERK1/2. Data represent the mean of three independent experiments, and the error bars indicate S.D. of triplicates 
cells were treated with the JNK1/2 inhibitor SP600125, with or without TNF $\alpha$. Cell death counting shows that inhibition of JNK1/2 phosphorylation rescues PC12 cells from TNF $\alpha$ induced apoptosis when the NF- $\kappa \mathrm{B}$ pathway is impaired (Figure 6c). Similarly, we characterized the apoptotic pathway induced by $\mathrm{TNF} \alpha$ in PC12 cells in which both JNK1/2 and ERK1/2 phosphorylation is inhibited. PC12 cells treated as in Figure 6c were also pretreated or not with PD98059. The inhibition of the JNK pathway is able to rescue PC12 cells from TNF $\alpha$-induced apoptosis when the MAPK/ERK pathway has also been blocked (Figure 6d). Finally, we show that the inhibition of the MAPK/ERK pathway by PD98059 leads to a sustained JNK1/2 phosphorylation and the upregulation of $\mathrm{Bim}$ as compared with cells treated with TNF $\alpha$ alone (Figure $6 e$ ), and in a similar manner to NF- $\kappa$ B inhibition (Figure 6a). Also, the simultaneous inhibition of the MAPK/ERK and the JNK pathway inhibits TNF $\alpha$-induced Bim upregulation (Figure 6e). Altogether, our results demonstrate that TNF $\alpha$ induces apoptosis when either NF- $\kappa$ B or the MAPK/ERK pathway is inhibited, and in both cases through the upregulation of the $\mathrm{BH}$-only protein Bim, which is under the control of JNK1/2 activation.

\section{Discussion}

In the present work, we describe the regulation of MAPK/ERK activation by TNF $\alpha$ in the neuronal PC12 cells. Our results suggest a signaling pathway triggered by TNF $\alpha$ and dependent on the regulation of FLIP-L by NF- $\kappa \mathrm{B}$. Moreover, we demonstrate that TNF $\alpha$-induced MAPK/ERK activation protects PC12 cells from apoptosis. Inhibition of MAPK/ERK pathway or $\mathrm{NF}-\kappa \mathrm{B}$ pathway renders cells sensitive to $\mathrm{TNF} \alpha-$ induced apoptosis through a pathway dependent on JNK1/2 phosphorylation. Therefore $\mathrm{NF}-\kappa \mathrm{B}$ has a crucial role in blocking the apoptotic signaling induced by TNF $\alpha$. Although the role of $\mathrm{NF}-\kappa \mathrm{B}$ as a regulator of cell survival, inflammation and immune response has been described extensively, ${ }^{14,43}$ its function in the nervous system remains controversial. While some studies have shown the importance of $N F-\kappa B$ in neuronal death, ${ }^{44}$ others using a reporter gene have demonstrated that constitutive NF- $\kappa \mathrm{B}$ activation is necessary for neuronal survival during development and in the adult brain. ${ }^{45}$ However, the stimuli that contribute to constitutive activation of $\mathrm{NF}-\kappa \mathrm{B}$ or the mechanism through which it promotes neuronal survival are unclear. In PC12 cells, the NF- $\kappa \mathrm{B}$ inducing kinase has been shown to induce cell differentiation and prevent apoptosis, inducing the activation of both $\mathrm{lkB} \alpha$ and MAPK. ${ }^{46}$ These results support our observations in the same cellular model where TNF $\alpha$ induces ERK1/2 phosphorylation to promote cell survival. In our model, the activation of $\mathrm{NF}-\kappa \mathrm{B}$ by $\mathrm{TNF} \alpha$ stimulation controls FLIP-L but not $\mathrm{Bcl}-\mathrm{xL}$ expression. ${ }^{15}$ Moreover, through a loss-of-function approach, we show that FLIP-L is essential for TNF $\alpha$-induced MAPK activation. Therefore, our results point to FLIP-L as the key regulator of this activation, linking the pro-survival function of $\mathrm{NF}-\kappa \mathrm{B}$ to the antiapoptotic role of FLIP-L. Supporting these observations, in a cellular model of lymphocytes, Kataoka et al. ${ }^{24}$ have previously demonstrated that activation of Fas by its specific ligand FasL promotes activation of NF- $\kappa$ B and ERK signaling pathways through the interaction of FLIP-L with Raf-1. We also report here the interaction of FLIP-L with Raf-1 in PC12 cells and Raf-1 activation after TNF $\alpha$ stimulation, which ultimately leads to the activation of ERK1/ 2 , without the upstream activation of Ras. Even though the interaction of FLIP-L with Raf-1 has been previously reported in different non-neuronal paradigms, it has never been linked to upstream Ras activation. ${ }^{47,48}$ Most importantly, we show that TNF $\alpha$-induced NF- $\kappa$ B activation, as well as FLIP-L and Raf-1 endogenous levels is essential for the activation of the MAPK/ERK pathway. Additional work is required to elucidate the detailed mechanistics of Raf-1 activation through its interaction with FLIP-L.

We have provided evidence for the role of MAPK/ERK as an inhibitor of TNF $\alpha$-induced apoptosis, as the constitutively active form of MEK rescues from apoptosis and treatment with a specific inhibitor of the MAPK/ERK pathway is able to sensitize cells to death induced by $\mathrm{TNF} \alpha$. Moreover, characterization of this apoptotic pathway has shown that it is very similar to the one observed when NF- $\kappa \mathrm{B}$ activation is blocked, thus further confirming the link between the NF- $\kappa \mathrm{B}$ pathway and the MAPK/ERK pathway. JNK1/2 seems to have a relevant role in the apoptotic pathway induced by TNF $\alpha$ when NF- $\kappa$ B is blocked or when the MAPK/ERK pathway is inhibited. It has been established that TNF $\alpha$ induces JNK1/2 activation, which can be repressed by NF- $\kappa$ B through the transcriptional regulation of gadd $45 \beta$ ref. 37 . When NF- $\kappa \mathrm{B}$ activation is impaired, TNF $\alpha$-induced JNK1/2 activation is maintained, inducing apoptotic cell death. ${ }^{31,39}$ However, the molecular mechanism through which prolonged JNK1/2 activation promotes cell death remains elusive. It has been previously reported that the $\mathrm{BH} 3$-only protein Bim has a central role in apoptosis induced by sustained JNK1/2 activation. ${ }^{41,42}$ In our model, TNF $\alpha$ induces an increase in Bim expression when NF- $\kappa \mathrm{B}$ activation is blocked by expression of the super-repressor of $\operatorname{lkB} \alpha$, or when the MAPK/ERK pathway is inhibited.

On the one hand, we have characterized the molecular players intervening in the apoptotic response that might be triggered upon TNF $\alpha$ stimulation, but only when the NF- $\kappa \mathrm{B}$ and/or MAPK pathway is blocked. On the other hand, we confirm the relevance of the MAPK/ERK activation in the TNF $\alpha$-induced survival decision by rescuing TNF $\alpha$-induced cell death with the NGF-induced MAPK activation. Our results clearly show that, unlike NGF that activates MAPK/ERK and $\mathrm{NF}-\kappa \mathrm{B}$ in two different and redundant pathways, ${ }^{29} \mathrm{TNF} \alpha$ treatment induces NF- $\kappa \mathrm{B}$ and MAPK/ERK activation in one unique pathway as blocking either component leads to the same biological response, more specifically JNK-mediated apoptosis. We demonstrate here that the activation of MAPK/ ERK is key for neuroprotection upon TNF $\alpha$ treatment, as apoptotic pathway triggered by NF- $\kappa \mathrm{B}$ inhibition in $\mathrm{TNF} \alpha$ treated PC12 cells can be rescued by the MAPK/ERK activation induced by NGF stimulation. While the role of MAPK/ERK activation by neurotrophins as mediators of neuronal survival, differentiation and synaptic plasticity has been well characterized, ${ }^{49}$ there is little information about the role of MAPK/ERK activation induced by DRs in the nervous system. Desbarats et al. ${ }^{30}$ described that Fas is able to induce neurite outgrowth in dorsal root ganglia neurons, through ERK activation and p35 upregulation. The group of Martin-Villalba 
links the activation of Fas by FasL to glioblastoma invasion mediated by PI3K/AKT and regulated by the Src family protein Yes. ${ }^{50}$ The TNF-like weak inducer of apoptosis (TWEAK) has a neuroprotective role in the central nervous system, since treatment with recombinant TWEAK or expression of its receptor Fn14-induced hypoxic and ischemic tolerance through TNF $\alpha$-induced ERK1/2 activation. ${ }^{51}$

Altogether, we present a mechanism through which NF- $\kappa \mathrm{B}$ is able to block TNF $\alpha$-induced apoptosis in a neuronal model. Our results provide an answer to questions related to observations done in the nervous system in which TNF $\alpha$ and other DRs, apart from their well-documented apoptotic role in neurodegenerative diseases, ${ }^{52-55}$ exert a protective role. This role seems relevant in physiological processes such as development of the nervous system, ${ }^{56}$ and pathological conditions, such as the protection provided by TNF family molecules after an ischemic insult. ${ }^{57}$ In summary, we have uncovered a single activation pathway for MAPK/ERK, regulated by $\mathrm{NF}-\kappa \mathrm{B}$ through the transcriptional regulation of the classical antiapoptotic protein FLIP-L, and directly involved in the regulation of neuronal death and survival.

\section{Materials and Methods}

Reagents. Recombinant human TNF $\alpha$ purchased from Biotrend (Köln, Germany) was used at $100 \mathrm{ng} / \mathrm{ml}$. Purified recombinant NGF was obtained from Alomone (Jerusalem, Israel). PD98059 (2'-amino-3'-methoxyflavone), SP600125 and fluorogenic caspase substrate Ac-DEVD-afc were purchased from Calbiochem/Merck Biosciences (San Diego, CA, USA). Unless otherwise specified, all biochemical reagents were purchased from Sigma-Aldrich (Barcelona, Spain).

Cell culture. Rat pheochromocytoma PC12 cells were grown in $100 \mathrm{~mm}$ culture dishes (Falcon Discovery Labware, BD Biosciences, San Agustin de Guadalix, Spain) in Dulbecco's Modified Eagle Medium supplemented with $6 \%$ heat-inactivated fetal bovine serum (FBS) and $6 \%$ heat-inactivated horse serum (HS) (Invitrogen, Barcelona, Spain), $10 \mathrm{mM} \mathrm{HEPES,} 20 \mathrm{U} / \mathrm{ml}$ penicillin, and $20 \mu \mathrm{g} /$ $\mathrm{ml}$ streptomycin. Cultures were maintained at $37^{\circ} \mathrm{C}$ in a humidified atmosphere of $95 \%$ air and $5 \% \mathrm{CO}_{2}$. PC12 cells were serum-deprived for $12-16 \mathrm{~h}$ prior treatment with TNF $\alpha$ or NGF. When pharmacological inhibitors were used, cells were pretreated with the indicated inhibitor for 30 min prior cotreatment with the given inhibitor and TNF $\alpha$.

Plasmids. Super-repressor $\mid \kappa \mathrm{B} \alpha\left(\mathrm{SR}-\left.\right|_{\kappa} \mathrm{B} \alpha\right)$ cDNA was expressed under the control of a cytomegalovirus constitutive promoter in the pcDNA3 expression vector (Invitrogen). FLIP-L-FLAG CDNA was subcloned into the pEIGW vector, giving rise to the lentiviral $p E I G W-F L I P-L-F L A G$ overexpressing construct. For RNA interference experiments, PLVTHM-shFLIP-L and its scrambled control plasmid that has been described and validated by Moubarak et al. ${ }^{29}$ were used for lentiviral knockdown experiments.

The Glu217-Glu221 MAPKK1 mutant construct (MEK-CA, constitutively active MAPKK1) was kindly provided by C E Marshall (Institute of Cancer Research, London, United Kingdom) through A López-Rivas (CSIC, Granada, Spain).

Cell transfection and infection. PC12 cells were transfected with the desired plasmid using Lipofectamine 2000 reagent (Invitrogen) following the manufacturer's instructions. PC12 cells stably expressing the super-repressor of $\mid \kappa \mathrm{B} \alpha, \mathrm{pcDNA3}-\mathrm{SR}-\mathrm{I}_{\kappa} \mathrm{B} \alpha$ or empty pcDNA3 (Neo) were obtained as described by Sole et al. ${ }^{58} \mathrm{PC} 12$ were transfected using Dharmafect (Dharmacon, ThermoFischer Scientific, Lafayette, CO, USA) with specific oligonucleotides targeting rat Raf-1, which sequence is as follows: $5^{\prime}$-UCACAACUUUGCUCGGAAA(dT)(dT)- $3^{\prime}$ (sense); 5'-UUUCCGAGCAAAGUUGUGA(dT)(dT)-3' (antisense). The siRNA used to silence Raf-1 was designed using the siDESIGN webpage (Thermo Fischer Scientific), and targets the nucleotide in position 414 of the open reading frame of rat Raf-1 (NCBI accession number NM_012639.2). shRNA lentiviral infection was performed when required, in order to assess the effects of FLIP-L knockdown by knockdown strategy or to overexpress FLIP-L. FLIP-L levels were assessed by western blot, and lentiviruses efficiently induced FLIP-L protein overexpression or reduced protein levels after 2 and 3 days of infection, respectively.

Lentiviral production. Lentiviruses were produced as described previously by Segura et al. ${ }^{59}$

Cell viability assays. For apoptotic nuclear morphology, cells were plated in 24-well plates at $5 \times 10^{4}$ cells/well, cultured for $24 \mathrm{~h}$ with complete growth medium and treated for the indicated times. Cells were then fixed with $2 \%$ paraformaldehyde and stained with $0.05 \mu \mathrm{g} / \mathrm{ml}$ of Hoechst 33258 for $30 \mathrm{~min}$ at room temperature. Condensed or fragmented nuclei (apoptotic nuclear morphology type II) were counted as dead cells as described by Yuste et al. ${ }^{60}$ The quantification of cell death by chromatin condensation was performed in blind testing, counting at least 300 cells for each data point, and was repeated at least three times in independent experiments.

Apoptosis was also assessed by TUNEL staining. Cells were fixed in $2 \%$ paraformaldehyde/PBS for $60 \mathrm{~min}$ at room temperature, permeabilized with $0.1 \%$ Triton-X-100 $0.1 \%$ sodium citrate for $20 \mathrm{~min}$ at $4{ }^{\circ} \mathrm{C}$ and stained following the In situ Cell Death Detection Kit instructions (Roche, Sant Cugat del Vallès, Spain). At the final step, Hoechst 33258 was added at a final concentration of $0.05 \mu \mathrm{g} / \mathrm{ml}$.

Caspase activity. After the indicated treatments, cells were rinsed once with PBS and resuspended in lysis buffer containing $20 \mathrm{mM} \mathrm{HEPES} / \mathrm{NaOH} \mathrm{pH} 7.2$, $10 \%$ sucrose, $150 \mathrm{mM} \mathrm{NaCl}, 10 \mathrm{mM}$ DTT, $5 \mathrm{mM}$ EDTA, $1 \%$ Nonidet P-40, $0.1 \%$ CHAPS and $1 \times$ EDTA-free complete protease inhibitor cocktail (Roche). Lysates were cleared by centrifugation at $16000 \times g$ for $5 \mathrm{~min}$. and supernatant proteins were quantified by the Bradford method. Assays were performed in triplicate using $25 \mu \mathrm{g}$ of protein in the same specific lysis buffer supplemented with $25 \mu \mathrm{M}$ of the fluorogenic substrate Ac-DEVD-afc. Plates were read in a fluorimeter using a $360-\mathrm{nm}$ ( $40 \mathrm{~nm}$ bandwidth) excitation filter and a $530-\mathrm{nm}$ ( $25 \mathrm{~nm}$ bandwidth) emission filter. Alternatively, we used the method described by Yuste et al., ${ }^{60}$ adding the cell lysis buffer with the fluorogenic substrate directly to the cells in the plate after treatment.

Immunofluorescence of RelA/p65 nuclear translocation. To determine NF- $\kappa$ B activation, we performed an immunofluorescence against $p 65$ to detect its nuclear translocation after treatment with $\mathrm{TNF} \alpha$, as described previously. ${ }^{58}$

Raf-1 translocation to the cytoplasmic membrane. The translocation of Raf-1 to the cytoplasmic membrane was determined by subfractionation. PC12 cells treated as indicated were rinsed once with ice-cold PBS $1 \times, \mathrm{pH} 7.2$ and scraped in subfractionation buffer (10 mM Hepes, pH 7.4, 2 mM EDTA, $1 \mathrm{mM}$ sodium orthovanadate) supplemented with $1 \times$ EDTA-free Complete protease inhibitor cocktail (Roche) and $1 \times$ phosphatase inhibitor cocktail 3 . Samples were sonicated and nuclei and cell debris were pelleted by centrifugation for $10 \mathrm{~min}$ at $800 \times g, 4^{\circ} \mathrm{C}$. Supernatants were harvested and centrifuged for $80 \mathrm{~min}$ at $100000 \times g, 4^{\circ} \mathrm{C}$. The supernatants were recovered and labeled as cytoplasmic fraction while pellets were solubilized in subfractionation buffer supplemented with Triton-X-100 $1 \%$, and incubated at $4{ }^{\circ} \mathrm{C}$ for $30 \mathrm{~min}$. This later fraction was labeled as membrane fraction. Laemmli buffer was added and samples were boiled for 5 min at $95^{\circ} \mathrm{C}$ prior western blotting.

Western blot. Cells were rinsed once with ice-cold PBS $1 \times, \mathrm{pH} 7.2$, and lysed in prewarmed $\left(95^{\circ} \mathrm{C}\right) 2 \% \mathrm{SDS} / 125 \mathrm{mM}$ Tris-pH6.8 lysis buffer. For detection of phosphorylated JNK, cells were rinsed once with ice-cold PBS, pH 7.2 and resuspended in IP lysis buffer composed $20 \mathrm{mM}$ Tris, pH 7.4, $140 \mathrm{mM} \mathrm{NaCl}, 10 \%$ glycerol, $1 \mathrm{mM}$ sodium orthovanadate, $40 \mathrm{mM} \beta$-glycerophosphate, $1 \% \mathrm{NP}-40$, supplemented with $1 \times$ EDTA-free complete protease inhibitor cocktail (Roche) and $1 \times$ phosphatase inhibitor cocktail 3 , prior centrifugation at $16000 \times g, 4^{\circ} \mathrm{C}$ and harvesting supernatants. Protein concentration was quantified by a modified Lowry assay (DC protein assay; Bio-Rad, Hercules, CA, USA). The cell lysates obtained (5-30 $\mu \mathrm{g}$ of protein) were resolved by SDS-polyacrylamide gels and transferred onto polyvinylidene difluoride Immobilon-P membranes (Millipore). After blocking with TBS $1 \times-0.1 \%$ Tween-20 containing $5 \%$ non-fat dry milk for $1 \mathrm{~h}$ at room temperature, membranes were probed with the appropriate primary antibodies, prior incubation for $1 \mathrm{~h}$ with the appropriate specific peroxidase- 
conjugated secondary antibody. Membranes were developed using the EZ-ECL chemiluminescence detection kit (Biological Industries, Kibbutz Beit Haemek, Israel) or SuperSignal Dura (Pierce/ThermoFisher Scientific, Lafayette, CO, USA). The primary antibodies used were the following: anti-phospho-ERK, anti-phosphoJNK, anti-total JNK (Cell Signaling Technologies, Beverly, MA, USA), anti-panERK (Millipore), anti-I $\kappa \mathrm{B} \alpha$, anti-p65, anti-Raf-1 (Santa Cruz, Biotechnology, Santa Cruz, CA, USA), anti-FLIP (Dave-2) (Alexis Biochemicals, Farmingdale, NY, USA), antiBid (R\&D systems, Benicia, CA, USA), anti-Bim (ProSci Incorporated, San Diego, CA, USA) and anti-Bcl-xL (BD Biosciences, Franklin Lakes, NJ, USA).

Immunoprecipitation. Cellular lysates were cleared by centrifugation at $16000 \times g$ and quantified by a modified Lowry assay (DC protein assay; Bio-Rad). One milligram of total protein was incubated with $5 \mu \mathrm{g}$ of anti-FLIP (Dave-2) antibody overnight at $4^{\circ} \mathrm{C}$. Immunocomplexes were collected with protein G-Sepharose by orbital shaking for $1 \mathrm{~h}$ at $4{ }^{\circ} \mathrm{C}$ and washed five times with IP lysis buffer. Beads were suspended in $40 \mu$ l of Laemmli's loading buffer and boiled, and samples were loaded onto an $8 \%$ SDS-polyacrylamide gel. As input controls, $25 \mu \mathrm{g}$ of the lysates were blotted with anti-FLIP (Dave-2) or cRaf antibody.

Determination of Ras activity. In order to determine Ras activity, we used a Ras activation assay kit (Millipore). In brief, the assay consists in the pull-down of active Ras (Ras-GTP) with GST-Raf-1 RBD coupled to glutathione-agarose, followed by Ras detection using a pan-Ras antibody.

Determination of Raf-1 kinase activity. In order to determine Raf-1 activity, we used a Raf-1 kinase assay kit with chemiluminescence detection (Millipore). Raf-1 dependent phosphotransferase activity is measured in a kinase reaction using recombinant MEK1 unactive as a Raf-1 substrate over PC12 lysates where Raf-1 was immunoprecipitated using anti-Raf-1 antibody (Santa Cruz, Biotechnology).

Statistical analysis. All the experiments were repeated at least three times. Values are expressed as mean \pm S.E.M.

\section{Conflict of Interest}

The authors declare no conflicts of interest.

Acknowledgements. We thank Dr Didier Trono (Geneve, Switzerland) for providing the lentiviral plasmids and Dr Miguel F Segura for critical reading of the manuscript. This work was funded by the Spanish Government 'Ministerio de Sanidad y Consumo' (CIBERNED, CB06/05/1104), 'Ministerio de Educación y Ciencia' (SAF2010-19953) and Generalitat de Catalunya (Suport als Grups de Recerca Consolidats 2009SGR346) to JXC, and 'Ministerio de Educación y Ciencia' SAF2011-24081 to VJY. FMF, LPF and KMOG are supported by postgraduate fellowships from the Spanish Government 'Ministerio de Educación y Ciencia'. RSM and VJY were under the Juan de la Cierva and the Ramon y Cajal programs, respectively, from the 'Ministerio de Educación y Ciencia' (Spain), cofinanced by the European Social Fund.

1. Yuan J, Yankner BA. Apoptosis in the nervous system. Nature 2000; 407: 802-809.

2. Breder CD, Tsujimoto M, Terano Y, Scott DW, Saper CB. Distribution and characterization of tumor necrosis factor-alpha-like immunoreactivity in the murine central nervous system. $J$ Comp Neurol 1993; 337: 543-567.

3. Choi $C$, Benveniste EN. Fas ligand/Fas system in the brain: regulator of immune and apoptotic responses. Brain Res Brain Res Rev 2004; 44: 65-81.

4. Neumann H, Schweigreiter R, Yamashita T, Rosenkranz K, Wekerle H, Barde YA. Tumor necrosis factor inhibits neurite outgrowth and branching of hippocampal neurons by a rho-dependent mechanism. J Neurosci 2002; 22: 854-862.

5. Park C, Sakamaki K, Tachibana O, Yamashima T, Yamashita J, Yonehara S. Expression of fas antigen in the normal mouse brain. Biochem Biophys Res Commun 1998; 252 623-628.

6. Shin DH, Lee E, Kim HJ, Kim S, Cho SS, Chang KY et al. Fas ligand mRNA expression in the mouse central nervous system. J Neuroimmunol 2002; 123: 50-57.

7. Beg AA, Baltimore D. An essential role for NF-kappaB in preventing TNF-alpha-induced cell death. Science 1996; 274: 782-784.

8. Park SM, Schickel R, Peter ME. Nonapoptotic functions of FADD-binding death receptors and their signaling molecules. Curr Opin Cell Biol 2005; 17: 610-616.

9. Micheau O, Tschopp J. Induction of TNF receptor I-mediated apoptosis via two sequential signaling complexes. Cell 2003; 114: 181-190.
10. Schneider-Brachert W, Tchikov V, Neumeyer J, Jakob M, Winoto-Morbach S, Held-Feindt $\mathrm{J}$ et al. Compartmentalization of TNF receptor 1 signaling: internalized TNF receptosomes as death signaling vesicles. Immunity 2004; 21: 415-428.

11. Schutze S, Tchikov V, Schneider-Brachert W. Regulation of TNFR1 and CD95 signalling by receptor compartmentalization. Nat Rev Mol Cell Biol 2008; 9: 655-662.

12. Karin M, Lin A. NF-kappaB at the crossroads of life and death. Nat immunol 2002; 3 : 221-227.

13. Micheau O, Lens S, Gaide O, Alevizopoulos K, Tschopp J. NF-kappaB signals induce the expression of C-FLIP. Mol Cell Biol 2001; 21: 5299-5305.

14. Van Antwerp DJ, Martin SJ, Kafri T, Green DR, Verma IM. Suppression of TNF-alphainduced apoptosis by NF-kappaB. Science 1996; 274: 787-789.

15. Gozzelino R, Sole C, Llecha N, Segura MF, Moubarak RS, Iglesias-Guimarais V et al. BCL-XL regulates TNF-alpha-mediated cell death independently of NF-kappaB, FLIP and IAPs. Cell Res 2008; 18: 1020-1036.

16. Wang CY, Mayo MW, Baldwin Jr AS. TNF- and cancer therapy-induced apoptosis: potentiation by inhibition of NF-kappaB. Science 1996; 274: 784-787.

17. Mahoney DJ, Cheung HH, Mrad RL, Plenchette S, Simard C, Enwere E et al. Both clAP1 and clAP2 regulate TNFalpha-mediated NF-kappaB activation. Proc Natl Acad Sci USA 2008; 105: 11778-11783.

18. Grossmann M, O'Reilly LA, Gugasyan R, Strasser A, Adams JM, Gerondakis S. The antiapoptotic activities of Rel and RelA required during $B$-cell maturation involve the regulation of $\mathrm{Bcl}-2$ expression. The EMBO journal 2000; 19: 6351-6360.

19. Vogler M. BCL2A1: the underdog in the BCL2 family. Cell Death Differ 2012; 19 : 67-74.

20. Chen C, Edelstein LC, Gelinas C. The Rel/NF-kappaB family directly activates expression of the apoptosis inhibitor Bcl-x(L). Mol Cell Biol 2000; 20: 2687-2695.

21. Irmler M, Thome M, Hahne M, Schneider P, Hofmann K, Steiner V et al. Inhibition of death receptor signals by cellular FLIP. Nature 1997; 388: 190-195.

22. Thome M, Schneider P, Hofmann K, Fickenscher H, Meinl E, Neipel F et al. Viral FLICEinhibitory proteins (FLIPs) prevent apoptosis induced by death receptors. Nature 1997; 386: $517-521$

23. Yeh WC, Itie A, Elia AJ, Ng M, Shu HB, Wakeham A et al. Requirement for Casper (c-FLIP) in regulation of death receptor-induced apoptosis and embryonic development. Immunity 2000; 12: 633-642.

24. Kataoka T, Budd RC, Holler N, Thome M, Martinon F, Irmler M et al. The caspase-8 inhibitor FLIP promotes activation of NF-kappaB and Erk signaling pathways. Curr Biol 2000; 10: 640-648.

25. Kataoka T, Schroter M, Hahne M, Schneider P, Irmler M, Thome M et al. FLIP prevents apoptosis induced by death receptors but not by perforin/granzyme $B$, chemotherapeutic drugs, and gamma irradiation. J Immunol 1998; 161: 3936-3942.

26. Tseveleki V, Bauer J, Taoufik E, Ruan C, Leondiadis L, Haralambous S et al. Cellular FLIP (long isoform) overexpression in T cells drives Th2 effector responses and promotes immunoregulation in experimental autoimmune encephalomyelitis. J Immunol 2004; 173: 6619-6626.

27. Raoul C, Henderson CE, Pettmann B. Programmed cell death of embryonic motoneurons triggered through the Fas death receptor. J Cell Biol 1999; 147: 1049-1062.

28. Taoufik E, Valable S, Muller GJ, Roberts ML, Divoux D, Tinel A et al. FLIP $(L)$ protects neurons against in vivo ischemia and in vitro glucose deprivation-induced cell death. $J$ Neurosci 2007; 27: 6633-6646.

29. Moubarak RS, Sole C, Pascual M, Gutierrez H, Llovera M, Perez-Garcia MJ et al. The death receptor antagonist FLIP-L interacts with Trk and is necessary for neurite outgrowth induced by neurotrophins. J Neurosci 2010; 30: 6094-6105.

30. Desbarats J, Birge RB, Mimouni-Rongy M, Weinstein DE, Palerme JS, Newell MK. Fas engagement induces neurite growth through ERK activation and p35 upregulation. Nat Cell Biol 2003; 5: 118-125.

31. Javelaud D, Besancon F. NF-kappa B activation results in rapid inactivation of JNK in TNF alpha-treated Ewing sarcoma cells: a mechanism for the anti-apoptotic effect of NF-kappa B. Oncogene 2001; 20: 4365-4372.

32. Tran SE, Holmstrom TH, Ahonen M, Kahari VM, Eriksson JE. MAPK/ERK overrides the apoptotic signaling from Fas, TNF, and TRAIL receptors. J Biol Chem 2001; 276: 16484-16490.

33. Xia Z, Dickens M, Raingeaud J, Davis RJ, Greenberg ME. Opposing effects of ERK and JNK-p38 MAP kinases on apoptosis. Science 1995; 270: 1326-1331.

34. Ahn JH, Park SM, Cho HS, Lee MS, Yoon JB, Vilcek J et al. Non-apoptotic signaling pathways activated by soluble Fas ligand in serum-starved human fibroblasts. Mitogenactivated protein kinases and NF-kappaB-dependent gene expression. J Biol Chem 2001; 276: 47100-47106.

35. Wallach D, Varfolomeev EE, Malinin NL, Goltsev YV, Kovalenko AV, Boldin MP. Tumor necrosis factor receptor and Fas signaling mechanisms. Ann Rev Immunol 1999; 17: 331-367.

36. Leevers SJ, Marshall CJ. Activation of extracellular signal-regulated kinase, ERK2, by p21ras oncoprotein. EMBO J 1992; 11: 569-574.

37. De Smaele E, Zazzeroni F, Papa S, Nguyen DU, Jin R, Jones $\mathrm{J}$ et al. Induction of gadd45beta by NF-kappaB downregulates pro-apoptotic JNK signalling. Nature 2001; 414: 308-313.

38. Tang G, Minemoto Y, Dibling B, Purcell NH, Li Z, Karin M et al. Inhibition of JNK activation through NF-kappaB target genes. Nature 2001; 414: 313-317. 
39. Wang Y, Singh R, Lefkowitch JH, Rigoli RM, Czaja MJ. Tumor necrosis factor-induced toxic liver injury results from JNK2-dependent activation of caspase-8 and the mitochondrial death pathway. J Biol Chem 2006; 281: 15258-15267.

40. Kaufmann T, Jost PJ, Pellegrini M, Puthalakath H, Gugasyan R, Gerondakis S et al. Fatal hepatitis mediated by tumor necrosis factor TNFalpha requires caspase- 8 and involves the BH3-only proteins Bid and Bim. Immunity 2009; 30: 56-66.

41. Putcha GV, Le S, Frank S, Besirli CG, Clark K, Chu B et al. JNK-mediated BIM phosphorylation potentiates BAX-dependent apoptosis. Neuron 2003; 38: 899-914.

42. Whitfield J, Neame SJ, Paquet L, Bernard O, Ham J. Dominant-negative c-Jun promotes neuronal survival by reducing BIM expression and inhibiting mitochondrial cytochrome $\mathrm{C}$ release. Neuron 2001; 29: 629-643.

43. Barkett M, Gilmore TD. Control of apoptosis by Rel/NF-kappaB transcription factors. Oncogene 1999; 18: 6910-6924.

44. Schneider A, Martin-Villalba A, Weih F, Vogel J, Wirth T, Schwaninger M. NF-kappaB is activated and promotes cell death in focal cerebral ischemia. Nat Med 1999; 5: 554-559.

45. Bhakar AL, Tannis LL, Zeindler C, Russo MP, Jobin C, Park DS et al. Constitutive nuclear factor-kappa B activity is required for central neuron survival. J Neurosci 2002; 22: 8466-8475.

46. Foehr ED, Bohuslav J, Chen LF, DeNoronha C, Geleziunas R, Lin X et al. The NF-kappa B-inducing kinase induces PC12 cell differentiation and prevents apoptosis. J Biol Chem 2000; 275: 34021-34024.

47. Gilbert S, Loranger A, Marceau N. Keratins modulate c-Flip/extracellular signal-regulated kinase 1 and 2 antiapoptotic signaling in simple epithelial cells. Mol Cell Biol 2004; 24: 7072-7081.

48. Piazzolla D, Meissl K, Kucerova L, Rubiolo C, Baccarini M. Raf-1 sets the threshold of Fas sensitivity by modulating Rok-alpha signaling. J Cell Biol 2005; 171: 1013-1022.

49. Chao MV. Neurotrophins and their receptors: a convergence point for many signalling pathways. Nat Rev Neurosci 2003; 4: 299-309.

50. Kleber S, Sancho-Martinez I, Wiestler B, Beisel A, Gieffers C, Hill O et al. Yes and PI3K bind CD95 to signal invasion of glioblastoma. Cancer cell 2008; 13: 235-248.

51. Echeverry R, Wu F, Haile WB, Wu J, Yepes M. The cytokine tumor necrosis factorlike weak inducer of apoptosis and its receptor fibroblast growth factor-inducible 14 have a neuroprotective effect in the central nervous system. J Neuroinflammation 2012; 9: 45.
52. He $\mathrm{P}$, Zhong Z, Lindholm K, Berning L, Lee W, Lemere $\mathrm{C}$ et al. Deletion of tumor necrosis factor death receptor inhibits amyloid beta generation and prevents learning and memory deficits in Alzheimer's mice. J Cell Biol 2007; 178: 829-841.

53. Jimenez S, Baglietto-Vargas D, Caballero C, Moreno-Gonzalez I, Torres M, Sanchez-Varo $\mathrm{R}$ et al. Inflammatory response in the hippocampus of PS1M146L/APP751SL mouse model of Alzheimer's disease: age-dependent switch in the microglial phenotype from alternative to classic. J Neurosci 2008; 28: 11650-11661.

54. Mc Guire C, Beyaert R, van Loo G. Death receptor signalling in central nervous system inflammation and demyelination. Trends in Neurosci 2011; 34: 619-628.

55. Nikolaev A, McLaughlin T, O'Leary DD, Tessier-Lavigne M. APP binds DR6 to trigger axon pruning and neuron death via distinct caspases. Nature 2009; 457: 981-989.

56. Martin-Villalba A, Herr I, Jeremias I, Hahne M, Brandt R, Vogel J et al. CD95 ligand (Fas-L $\mathrm{APO}-1 \mathrm{~L})$ and tumor necrosis factor-related apoptosis-inducing ligand mediate ischemiainduced apoptosis in neurons. J Neurosci 1999; 19: 3809-3817.

57. Esposito E, Cuzzocrea S. Anti-TNF therapy in the injured spinal cord. Trends in Pharmacol Sci 2011; 32: 107-115.

58. Sole C, Dolcet X, Segura MF, Gutierrez H, Diaz-Meco MT, Gozzelino R et al. The death receptor antagonist FAIM promotes neurite outgrowth by a mechanism that depends on ERK and NF-kapp B signaling. J Cell Biol 2004; 167: 479-492.

59. Segura MF, Sole C, Pascual M, Moubarak RS, Perez-Garcia MJ, Gozzelino R et al. The long form of Fas apoptotic inhibitory molecule is expressed specifically in neurons and protects them against death receptor-triggered apoptosis. $J$ Neurosci 2007; 27: 11228-11241.

60. Yuste VJ, Bayascas JR, Llecha N, Sanchez-Lopez I, Boix J, Comella JX. The absence of oligonucleosomal DNA fragmentation during apoptosis of IMR-5 neuroblastoma cells: disappearance of the caspase-activated DNase. J Biol Chem 2001; 276: 22323-22331.

Cell Death and Disease is an open-access journal published by Nature Publishing Group. This work is licensed under the Creative Commons Attribution-NonCommercial-No Derivative Works 3.0 Unported License. To view a copy of this license, visit http://creativecommons.org/licenses/by-nc-nd/3.0/ 